\title{
Type 1 Inositol Trisphosphate Receptor Regulates Cerebellar Circuits by Maintaining the Spine Morphology of Purkinje Cells in Adult Mice
}

\author{
Takeyuki Sugawara, ${ }^{1}$ Chihiro Hisatsune, ${ }^{1}$ Tung Dinh Le, ${ }^{2}$ Tsutomu Hashikawa, ${ }^{3}$ Moritoshi Hirono, ${ }^{2}$ Mitsuharu Hattori, ${ }^{4}$ \\ Soichi Nagao, ${ }^{2}$ and Katsuhiko Mikoshiba ${ }^{1,5}$ \\ Laboratories for ${ }^{1}$ Developmental Neurobiology, ${ }^{2}$ Motor Learning Control, and ${ }^{3}$ Neural Architecture, RIKEN Brain Science Institute, Wako, Saitama \\ 351-0198, Japan, ${ }^{4}$ Department of Biomedical Science, Graduate School of Pharmaceutical Sciences, Nagoya City University, Mizuho-ku, Nagoya, Aichi \\ 467-8603, Japan, and ${ }^{5}$ Calcium Oscillation Project, ICORP-SORST, Japan Science and Technology Agency, Kawaguchi, Saitama 332-0012, Japan
}

The structural maintenance of neural circuits is critical for higher brain functions in adulthood. Although several molecules have been identified as regulators for spine maintenance in hippocampal and cortical neurons, it is poorly understood how Purkinje cell (PC) spines are maintained in the mature cerebellum. Here we show that the calcium channel type 1 inositol trisphosphate receptor (IP $\left.{ }_{3} \mathrm{R} 1\right)$ in $\mathrm{PCs}$ plays a crucial role in controlling the maintenance of parallel fiber (PF)-PC synaptic circuits in the mature cerebellum in vivo. Significantly, adult mice lacking $\mathrm{IP}_{3} \mathrm{R} 1$ specifically in PCs $\left(\right.$ L7-Cre; Itpr $\left.1^{\text {floxfflox }}\right)$ showed dramatic increase in spine density and spine length of PCs, despite having normal spines during development. In addition, the abnormally rearranged PF-PC synaptic circuits in mature cerebellum caused unexpectedly severe ataxia in adult $L 7$-Cre; Itpr $1^{\text {flox/flox }}$ mice. Our findings reveal a specific role for IP ${ }_{3} \mathrm{R} 1$ in PCs not only as an intracellular mediator of cerebellar synaptic plasticity induction, but also as a critical regulator of PF-PC synaptic circuit maintenance in the mature cerebellum in vivo; this mechanism may underlie motor coordination and learning in adults.

\section{Introduction}

The cerebellum is a brain region that plays an important role in motor coordination and learning. In the cerebellar cortex, the Purkinje cells (PCs) are the sole output; they integrate numerous synaptic inputs from granule cells (GCs) and inferior olive neurons (Ito, 2006). In the distal dendritic region of PCs, a high density of spines is innervated by parallel fiber (PF) axons of GCs, while in the proximal region, a few spines are innervated by climbing fiber (CF) axons of inferior olive neurons (Ito, 2002; Lee et al., 2005). Synapses between PF terminals and PC spines are sites for cerebellar synaptic plasticity-long-term depression (LTD) and long-term potentiation-which are involved in certain types of motor learning and are thought to be the primary

Received Feb. 5, 2013; revised May 21, 2013; accepted June 15, 2013.

Author contributions: T.S., C.H., S.N., and K.M. designed research; T.S., T.D.L., T.H., M. Hirono, and M. Hattori performed research; T.S., T.D.L., T.H., and M. Hirono analyzed data; T.S., C.H., and K.M. wrote the paper.

This work was supported by grants from the RIKEN Brain Science Institute (BSI) and The Moritani Scholarship Foundation (to C.H.); and by Japan Society for the Promotion of Science Grants-in-Aid for Scientific Research 20500301 (to C.H.) and 20220007 (to K.M.). We thank Dr. K. Kawaai, Dr. H. Ando, Dr. A. Mizutani, and Dr. Y. Kuroda for valuable discussions. We also thank Ms. M. Kudo, Mr. T. Suzuki, and Dr. T. Okamoto for technical assistance. We thank the staffs of the BSI Research Resources Center for animal care. We also thank Dr. C. Yokoyama and Dr. A.V. Terashima for editing of this manuscript.

The authors declare no competing financial interests.

Correspondence should be addressed to either Chihiro Hisatsune or Katsuhiko Mikoshiba, RIKEN Brain Science Institute, Laboratory for Developmental Neurobiology, 2-1 Hirosawa, Wako, Saitama 351-0198, Japan. E-mail: chihiro@brain.riken.jp or mikosiba@brain.riken.jp.

M. Hirono's present address: Organization for Advanced Research and Education, Doshisha University, 4-1-1 Kizugawadai, Kizugawa, Kyoto 619-0225, Japan.

DOI:10.1523/JNEUROSCI.0545-13.2013

Copyright $\odot 2013$ the authors $\quad 0270-6474 / 13 / 3312186-11 \$ 15.00 / 0$ site where information needed to execute coordinated movements is stored (Jörntell and Hansel, 2006). Therefore, precise control of spine maintenance on distal dendrites of mature PCs is essential to maintain cerebellar neural circuits and their behavioral functions, but the molecular mechanism underlying this phenomenon is largely unknown.

Inositol trisphosphate receptors $\left(\mathrm{IP}_{3} \mathrm{Rs}\right)$ are calcium $\left(\mathrm{Ca}^{2+}\right)$ channels that are responsible for $\mathrm{Ca}^{2+}$ mobilization from intracellular sores in the endoplasmic reticulum (ER; Berridge et al., 2000). Three subtypes of this receptor have been identified, namely, $\mathrm{IP}_{3} \mathrm{R} 1, \mathrm{IP}_{3} \mathrm{R} 2$, and $\mathrm{IP}_{3} \mathrm{R} 3$ (Furuichi and Mikoshiba, 1995; Patel et al., 1999), with $\mathrm{IP}_{3} \mathrm{R} 1$ predominantly expressed in the CNS, especially in cerebellar PCs (Furuichi et al., 1993). $\mathrm{IP}_{3} \mathrm{Rs}$ have been shown to play crucial roles in several neuronal functions (Mikoshiba, 2011). In particular, $\mathrm{IP}_{3} \mathrm{R} 1$-null mice display seizure-like movements and ataxia (Matsumoto et al., 1996), impaired cerebellar LTD (Inoue et al., 1998), and abnormal PC dendritic morphology (Hisatsune et al., 2006). $\mathrm{IP}_{3}$ R1-heterozygous mice show motor discoordination (Ogura et al., 2001), suggesting that $\mathrm{IP}_{3} \mathrm{R} 1$ plays an important role in cerebellar function in vivo. However, because of the broad expression of $\mathrm{IP}_{3} \mathrm{R} 1$ in the $\mathrm{CNS}$, in addition to juvenile lethality of $\mathrm{IP}_{3} \mathrm{R} 1$-null mice (Furuichi et al., 1993; Matsumoto et al., 1996), it remains unclear how $\mathrm{IP}_{3} \mathrm{R} 1$ in PCs contributes to cerebellar function in adult mice.

To investigate the specific contribution of $\mathrm{IP}_{3} \mathrm{R} 1$ in $\mathrm{PCs}$ for cerebellar function in adult mice, we generated mice that specifically lacked $\mathrm{IP}_{3} \mathrm{R} 1$ in PCs (L7-Cre; Itpr $\left.1^{\text {flox/flox }}\right)$. We found that the loss of $\mathrm{IP}_{3} \mathrm{R} 1$ in PCs is sufficient to cause severe ataxia, impaired cerebellar learning, and PF-PC LTD. Furthermore, we found that 

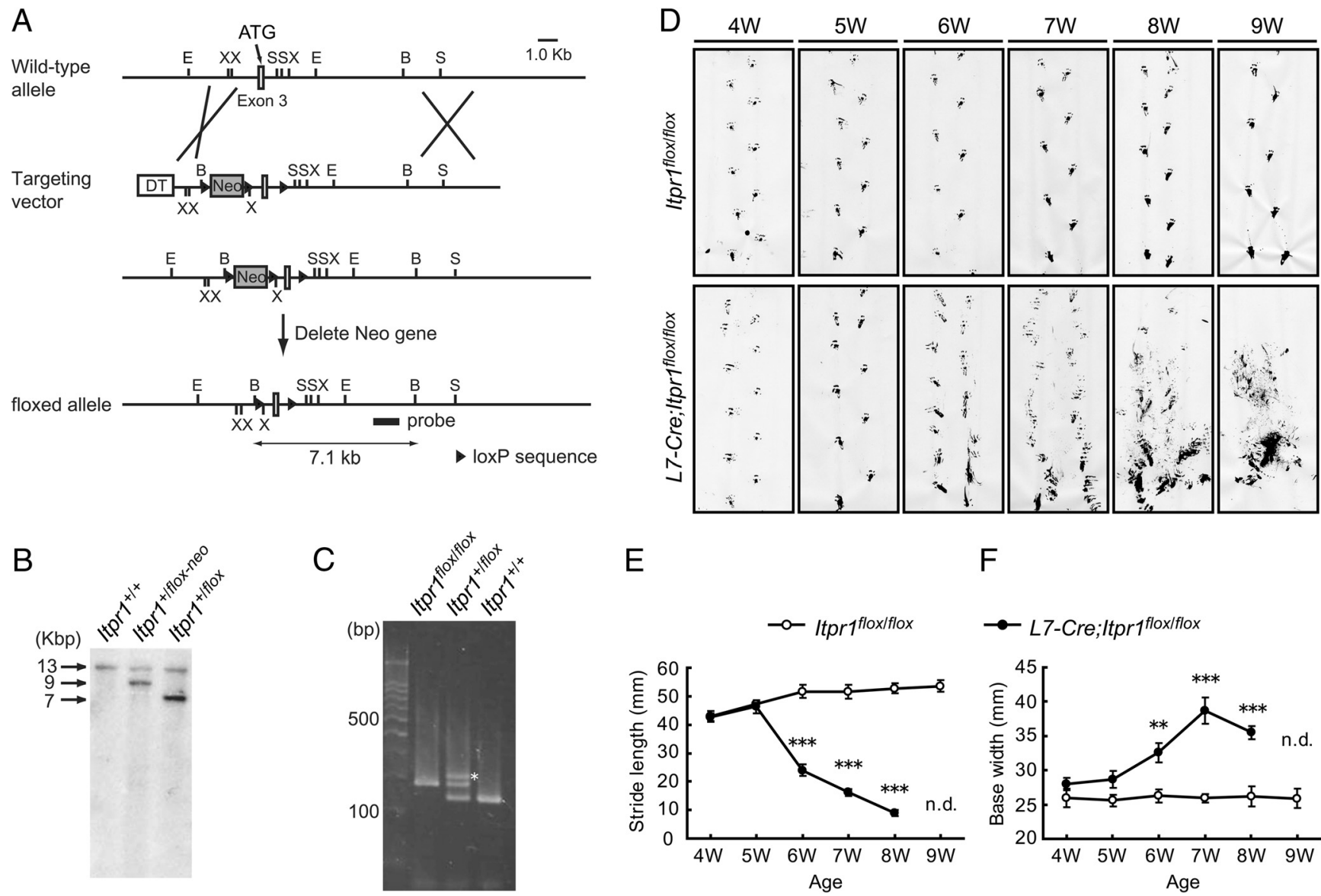

$\mathrm{F}$

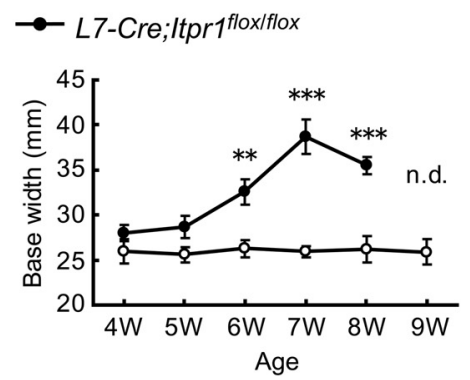

Figure 1. Severe cerebellar ataxia in adult L7-Cre; Itpr $7^{\text {flox } f \text { flox }}$ mice. $A$, Schematic diagram of the procedure for generating floxed Itpr 1 ES clones. Top, Wild-type Itpr 1 locus. Open box indicates the exon 3 of Itpr 1 in which the initiation ATG codon is localized. Middle, Targeting vector in which a loxP site was inserted at both sides of exon 3; a phosphogylcerol kinase-neo gene cassette and a diphtheria toxin A marker (DT) was inserted at the 5' end at the exon 3. Bottom, Floxed Itpr 1 locus with deleted neo cassette gene. Restriction enzyme abbreviations are as follows: E, EcoRl; S, Sall; B, BamHI; X, Xbal. B, Southern blot of genome digested with BamHI using a probe indicated in A. C, Genotyping of floxed Itpr 1 by PCR. Asterisk indicates a hybrid product of PCR product derived from wild-type and floxed alleles. $\boldsymbol{D}$, Representative footprints of $/$ tpr $7^{\text {flox fflox }}$ and $L 7-\left(r e ; / \operatorname{tpr} 7^{\text {flox } x \text { flox }}\right.$ mice at $4 \mathrm{~W}, 5 \mathrm{~W}, 6 \mathrm{~W}, 7 \mathrm{~W}, 8 \mathrm{~W}$, and $9 \mathrm{~W}$. The walking patterns were recorded from mice hindpaws. $\boldsymbol{E}$, $\boldsymbol{F}$, Quantitative analysis of footprint patterns for stride length $(\boldsymbol{E})$ and base width $(\boldsymbol{F})$ from $/ \operatorname{tpr} 7^{\text {floxfllox }}$ (white circles) and L7-Cre;/tpr $7^{\text {flox/flox }}$ (black circles) mice at 4W, 5W, 6W, 7W, 8W, and 9W ( $n=$ 3 mice; ${ }^{* *} p<0.01,{ }^{* * *} p<0.0001, t$ test and Mann-Whitney U test). n.d., Not determined.

L7-Cre;Itpr $1^{\text {floxfflox }}$ mice displayed abnormalities in spine density and morphology, as well as in dendritic branching of mature PCs, despite showing normal PC morphology during development. Our findings suggest that $\mathrm{IP}_{3} \mathrm{R} 1$ in PCs is essential for motor coordination and learning by controlling the maintenance of structural and functional circuits in the mature cerebellum in vivo.

\section{Materials and Methods}

Mice. Floxed Itpr1 (Itpr flox $)$ mice were generated using homologous recombination, which is a standard gene-targeting technique. The structure of the target vector is available in Figure 1A. The targeting construct was created from DNA cloned from a 129/SV mouse genomic DNA library. A neomycin-resistant (neo) gene flanked by 34 bp loxP sites, which was under the phosphogylcerol kinase promoter, was inserted into the intron between exon 2 and exon 3 of the Itprl gene. A 34 bp loxP sequence was also inserted downstream of exon 3, which contained the first methionine of Itprl gene. The DNA was then electroporated into 129/SvEv embryonic stem (ES) cells. G418-resistant ES cell clones were selected and screened by Southern blot analysis for homologous recombination with a $\sim 1.0 \mathrm{~kb}$ probe. The neo gene of the neo-positive ES clones was removed by electroporation of a Cre recombinase-expressing vector, and neo-deleted ES clones were screened by Southern blotting. Four clones were used for generating chimeras by microinjection into C57BL/6J blastocysts and implantation into pseudopregnant foster mothers.
Chimeric male mice were mated to C57BL/6J females, and offspring carrying the floxed Itprl were selected by PCR using the following primer pairs: primer A, 5' -CTTCTACCTAATCCCAGCCAGGGAATC-3'; primer B, 5' CTGGGTTAAGGAATCAAAGCAACAAG-3'; primer $\mathrm{H}$, $5^{\prime}$-ATCAGTTT TGCCTTCTCTAGA-3' for the $5^{\prime}$ loxP insertion; and primer E, $5^{\prime}$-TACA TAGATCCAAAGAAGTGCCTCTG- $3^{\prime}$, and primer F, $5^{\prime}$-AGGTTGAGTG ATGACTGATTGGAGG- $3^{\prime}$ for the $3^{\prime}$ loxP insertion in the gene. The mice were crossed with C57BL/6J at least 10 times. To generate $L 7-C r e ; I t p r 1^{\text {flox/flox }}$ mice, homozygous Itpr $1^{f l o x}$ mice were crossed with mice heterozygous for Itpr $1^{\text {flox }}$ and for an L7-Cre transgene (Barski et al., 2000). To generate L7-Cre; Itpr $^{\text {flox/flox }}$; $c$ cp2-GFP mice, we used Pcp2-GFP mice obtained from Jackson Laboratory (Tomomura et al., 2001). Mice were bred in a pathogen-free environment, and all experiments were performed in accordance with the guidelines approved by the Animal Experiments Committee of RIKEN Brain Science Institute. Both female and male mice were included in the analysis.

Antibodies. Rat monoclonal anti-IP ${ }_{3} \mathrm{R} 1$ (4C11, 18A10) antibodies were described previously (Maeda et al., 1990; Nakade et al., 1994). Mouse monoclonal and rabbit polyclonal anti-calbindin (Swant), mouse monoclonal anti- $\beta$-actin (clone AC-15; Sigma), mouse monoclonal anti-GFP (clone 1E4; MBL), rabbit polyclonal anti-VGluT1 (Synaptic Systems), and mouse monoclonal anti-VGluT2 (Millipore) antibodies were purchased.

Immunostaining and Nissl staining. For immunohistochemistry of cerebellar sections, mice were deeply anesthetized with pentobarbital and 
transcardially perfused with saline and $0.1 \mathrm{M}$ phosphate buffer $(\mathrm{PB})$ containing $4.0 \%$ paraformaldehyde (PFA). The brains were dissected and postfixed in PFA at $4^{\circ} \mathrm{C}$ for $3 \mathrm{~h}$, and then immersed in $30 \%$ sucrose in $\mathrm{PB}$ overnight at $4^{\circ} \mathrm{C}$. Except for GFP and type 2 vesicular glutamate transporter (VGluT2) immunostaining, the brains were sectioned sagittally at $8.0 \mu \mathrm{m}$ thickness using a cryostat (HM550; MICROM). The sections were blocked with $1.0 \%$ skim milk and $1.0 \%$ normal goat serum (Vector Laboratories) in PBS, and then incubated with the primary antibodies overnight at $4^{\circ} \mathrm{C}$. After being washed with PBS, sections were incubated with Alexa Fluor 488-conjugated and Alexa Fluor 594-conjugated secondary antibodies (Invitrogen). Stained sections were mounted with Vectashield (Vector Laboratories). For GFP and VGluT2 immunostaining, the brains were sectioned sagittally at $30 \mu \mathrm{m}$ thickness using a Vibratome tissue slicer (VT1000S; Leica Microsystems). PBS containing $0.3 \%$ Triton X-100 was used in GFP immunostaining. Other staining steps are described above. The primary antibodies used were $4 \mathrm{C} 11(1.0 \mu \mathrm{g} / \mathrm{ml})$, monoclonal anti-calbindin (1:1000), polyclonal anti-calbindin (1:2000), monoclonal anti-GFP (1:500), polyclonal anti-VGluT1 (1:2000), and monoclonal anti-VGluT2 (1:2000) antibodies. Distal dendrites of PCs located in lobule VI where $\mathrm{IP}_{3} \mathrm{R} 1$-positive PCs could be detected even in adult L7-Cre;Itpr $1^{\text {flox/flox }}$ mice (Fig. 2C) were examined to assess the relationship between $\mathrm{IP}_{3} \mathrm{R} 1$ expression and spine density in $\mathrm{L7}-\mathrm{Cre}$; Itpr $1^{\text {flox/flox }}$ mice PCs (Fig. 3C,D).

For Nissl staining, sections were incubated with warmed cresyl violet solution $[0.1 \%$ cresyl violet acetate (Sigma) $/ 0.07 \%$ acetic acid]. Nisslstained sections were differentiated in $80 \%$ ethanol, dehydrated in $99.5 \%$ ethanol, cleared in xylene, and then mounted with Permount (Fisher Scientific). All images were obtained using a Bio-zero BZ-8000 microscope (Keyence), with $4 \times$ [PlanApo, numerical aperture (NA) 0.2 ; Nikon] and $20 \times$ (PlanApo, NA 0.75; Nikon) objectives. Brain size was measured using ImageJ software (http://rsbweb.nih.gov/ij/).

Golgi staining. Three- or 10-week-old brains were stained using modified Golgi-Cox impregnation of neurons following the manufacturer's protocol (FD NeuroTechnologies). The brains were sectioned sagittally at $100 \mu \mathrm{m}$ thickness using a Vibratome tissue slicer. Golgi-impregnated sections were counterstained with Nissl staining. All images were obtained by using an ECLIPSE-

80i phase-contrast microscope (Nikon) with a $40 \times$ objective (Plan Fluor, NA 0.75; Nikon) or $100 \times$ oil-immersion objective (Plan Fluor, NA 1.3; Nikon). The branch points of PCs were manually counted and were used as a measure for PC dendritic branching. Because the deletion of $\mathrm{IP}_{3} \mathrm{R} 1$ in $L 7$ Cre; Itpr $1^{\text {floxfflox }}$ mice was significant particularly in the anterior lobule (Fig. $2 C$ ), we assayed PCs that were located in the anterior lobule for analysis in this study (unless otherwise noted).

Immunoblotting. Crude microsome fractions of mouse cerebella were obtained as described previously (Yoshikawa et al., 1999; Mizutani et al., 2008). Fractions were loaded on 6.5\% SDS-PAGE and transferred onto a polyvinylidene difluoride membrane (Millipore). The membrane was blocked with 5.0\% skim milk in PBST (PBS containing 0.05\% Tween 20) and then incubated with the primary antibodies for $1 \mathrm{~h}$ at room temperature or overnight at $4^{\circ} \mathrm{C}$. The primary antibodies used were $18 \mathrm{~A} 10(1.0$
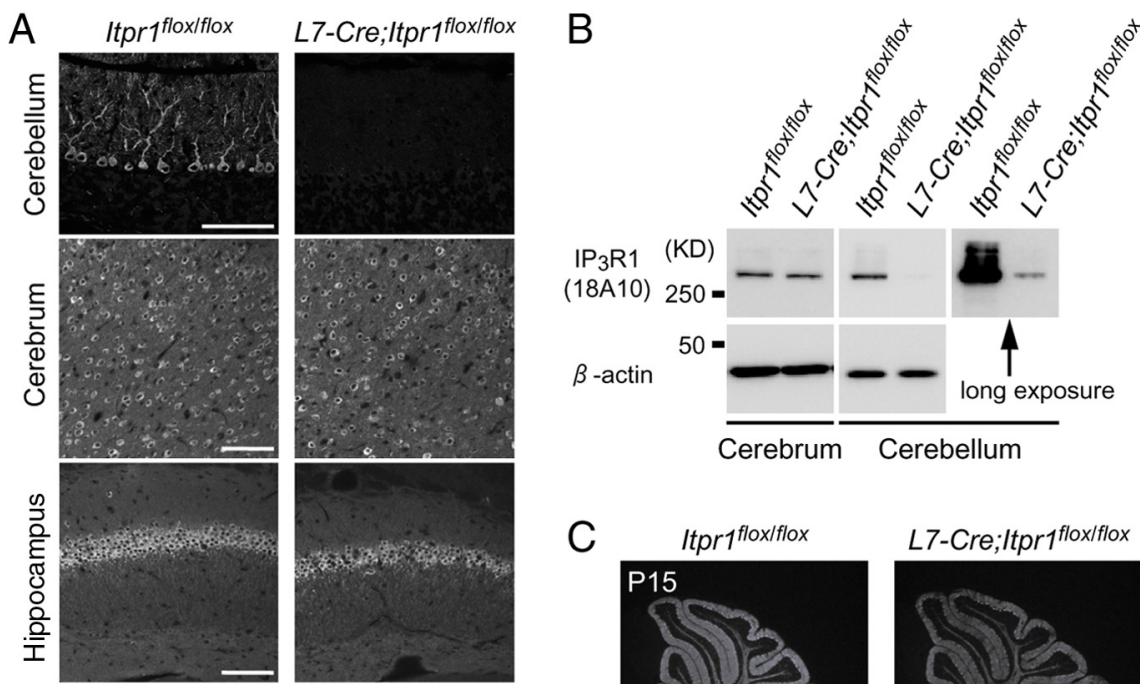

$\mathrm{IP} \mathrm{P}_{3} \mathrm{P}$

(18A10)

(KD)

$\beta$-actin

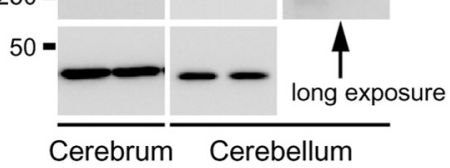

C

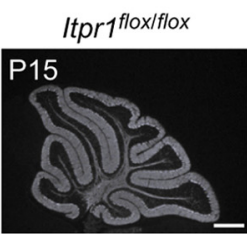

L7-Cre;Itpriflox/flox
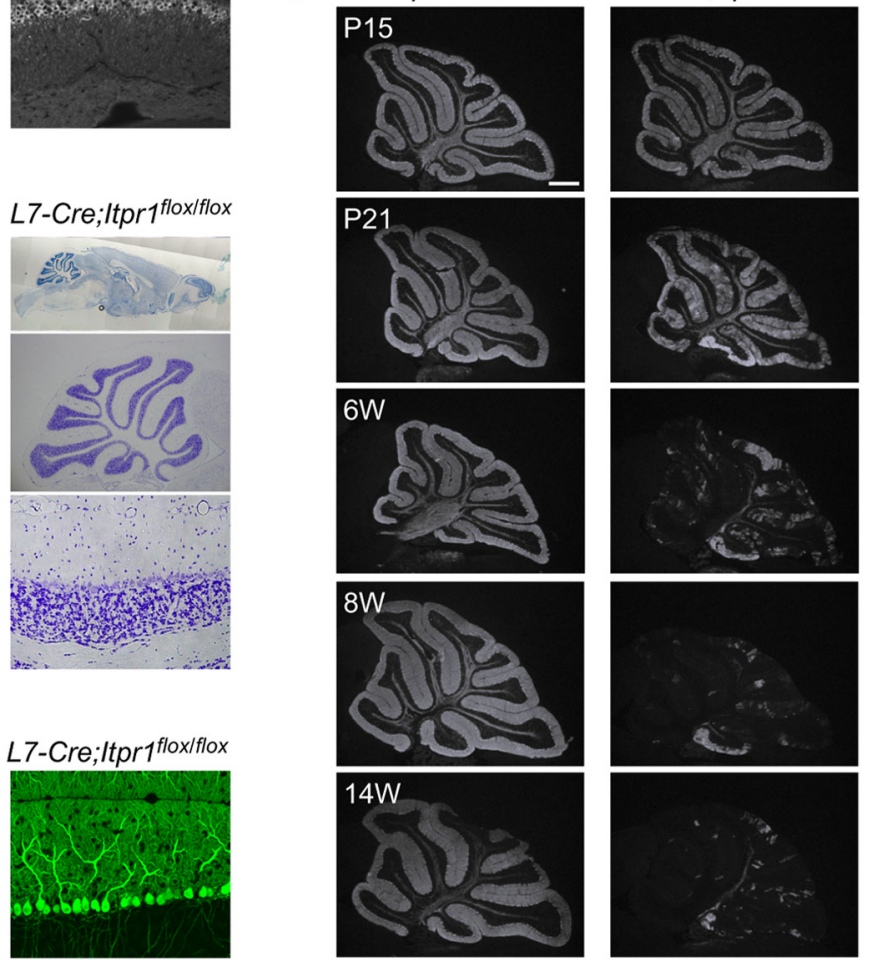

Figure 2. Characterization of $L 7-C r e, I t p r 7^{\text {floxfflox }}$ mice. $A$, Immunohistochemical analysis of IP R1 proteins in the cerebellum, cerebral cortex, and hippocampus. Sagittal sections prepared from control Itpr $7^{\text {flox/flox }}$ and L7-Cre;/tpr $7^{\text {flox }}{ }^{\text {fllox }}$ mice at $10 \mathrm{~W}$ were cerebellum. Membrane fractions prepared from cortex or cerebellum of $/ \mathrm{tpr} 7^{\text {flox } f f l o x}$ and $L 7-C \mathrm{Cre}, \mathrm{Itpr} 7^{\text {flox fflox }}$ mice at $8 \mathrm{~W}$ were probed with the antibodies indicated. C, Immunohistochemical analysis of the expression level of IP R1 protein in the cerebellar PCs at with anti-IP $P_{3} R 1$ antibody (4C11). Scale bar, $500 \mu \mathrm{m}$. D, Nissl staining of sagittal sections of the cerebellar vermis prepared from mice at 10W. The bottom panels show magnified views of the middle panels. Scale bars: top, $1 \mathrm{~mm}$; middle, $500 \mu \mathrm{m}$; bottom, 50 $\mu \mathrm{m} . \boldsymbol{E}$, Immunostaining for calbindin of sagittal sections of the cerebellar vermis prepared from mice at 10W. Scale bar, $50 \mu \mathrm{m}$.

$\mu \mathrm{g} / \mathrm{ml})$ and monoclonal anti- $\beta$-tubulin (1:5000) antibodies. After washing with PBST, the membrane was incubated with horseradish peroxidase-conjugated secondary antibody (1:5000; GE Healthcare) for $1 \mathrm{~h}$ at room temperature. The blot was developed using chemiluminescence reagents (Immobilon Western Chemiluminescent HRP Substrate; Millipore) and detected using an image analyzer (LAS-4000 mini; FUJIFILM).

Footprint analysis. Mouse hindpaws were dipped in nontoxic waterbased black paints. Mice were then allowed to walk down an enclosed runway lined with white paper. The footprint patterns were analyzed for the following two parameters: stride length and base width. Stride length was measured as the average distance between two consecutive paw prints on the same side. Three consecutive strides were measured for each paw per animal. Base width was measured as the average distance be- 
A
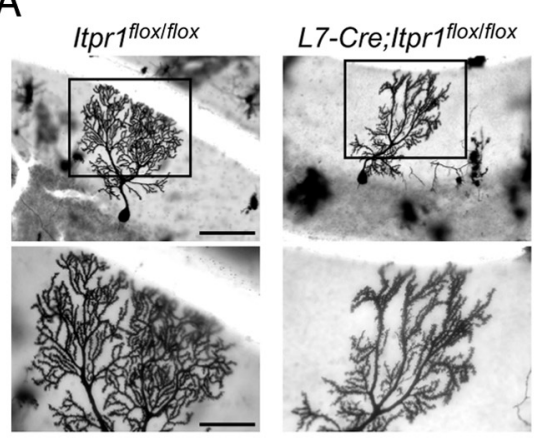

$B$

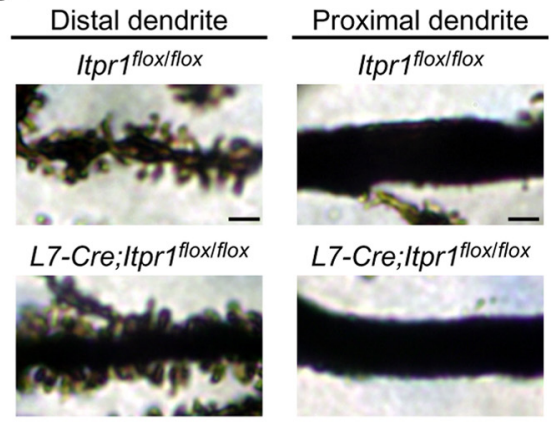

C

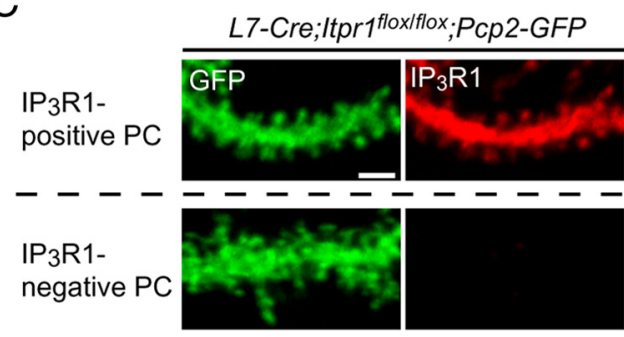

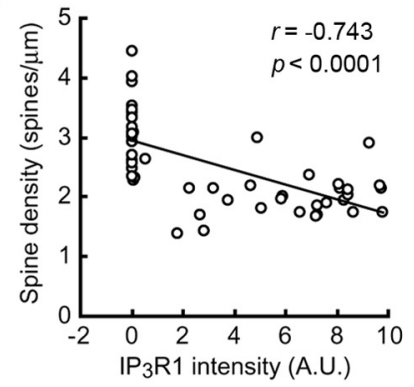

E

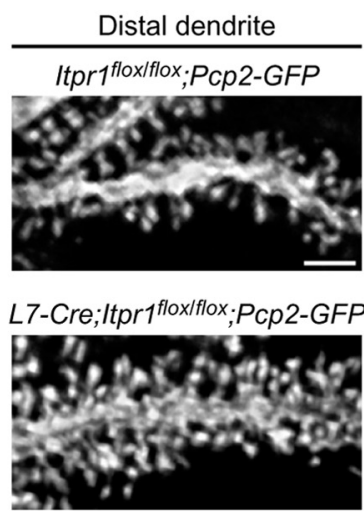

Proximal dendrite

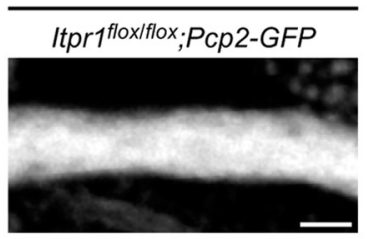

L7-Cre;Itpr1flox/flox;Pcp2-GFP

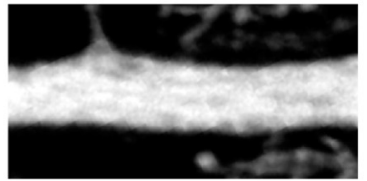

Figure 3. Abnormal PC dendritic and spine morphology from adult L7-Cre;/tpr $7^{\text {flox/flox }}$ mice. $\boldsymbol{A}$, Golgi-stained PCs from Itpr $7^{\text {flox/flox }}$ and L7-Cre;ltpr $7^{\text {flox/flox }}$ mice at 10W. Low-magnification images (top) and magnified images (bottom) are shown. Scale bars: top, $100 \mu \mathrm{m}$; bottom, $50 \mu \mathrm{m}$. B , Higher-magnification views of distal dendritic (left) and proximal dendritic (right) regions of Golgi-stained PCs. Scale bars, $2 \mu \mathrm{m}$. C, Relationship between abnormal spine density and loss of $I P_{3} R 1$ in PCs of adult $L 7-C r e ; / t p r 7^{\text {flox/flox }}$ mice. Cerebellar sagittal sections prepared from $L 7-C r e ; / t p r 7^{f l o x} /$ flox mice at $10 \mathrm{~W}$ were coimmunostained with anti-GFP (green) and anti-IP ${ }_{3} \mathrm{R} 1$ antibodies (4C11; red). Representative images of distal dendrites of $I P_{3} R 1$-positive (top panels) and $I P_{3} R 1$-negative (bottom panels) PCs located in lobule VI are shown. Scale bar, $2 \mu \mathrm{m}$. D, Plot of spine density along distal dendrites versus average fluorescence intensity for $I P_{3} R 1$ in distal dendrites

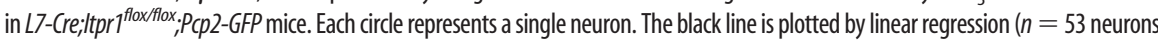
from two mice; $r=-0.743, p<0.0001$,Spearman correlation analysis). A.U., Arbitrary units. $E$, Spines on distal (left) and proximal (right)

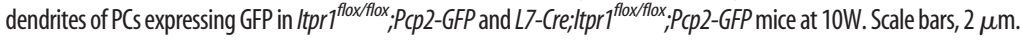

tween the center of the left and right hind footprints. Four base widths were measured for each animal.

Fluorescent image acquisition and image analysis. Fluorescent images were obtained using a fluorescent microscope (Biozero BZ-8000) with a $4 \times$ objective (PlanApo, NA 0.2; Nikon) and a confocal laser microscope (FV-1000; Olympus) with $20 \times$ (UPlanApo, NA 0.7; Olympus), 40× (UPlanApo, NA 1.0; Olympus), or $60 \times$ (PlanApoN, NA 1.42; Olympus) oil-immersion objective. For quantification of PC density and soma area, a series of images of sections at $1.0 \mu \mathrm{m}$ intervals were obtained. Calbindin-positive cells were counted for PC density and used for the measurement of PC soma area. For spine analysis, a series of images of sections at $0.1-0.5 \mu \mathrm{m}$ intervals were obtained. Spine density and morphology were quantified. For synapse analysis, the percentage of spines contact with PFs was determined by colocalization analysis. Each spine of GFP-positive PCs was classified as positive or negative depending on its colocalization with the presynaptic terminal signal of VGluT1. To assess the thickness of the molecular layer and the height of the CF extending along the PC dendrite, a series of images of sections at $1.0 \mu \mathrm{m}$ intervals was obtained. Molecular layer thickness was measured as the distance from the top of the PC soma to the end of the dendrite near the pial surface. The VGluT2 signal was used to determine $\mathrm{CF}$ terminal deposition. For determining the extent of CF innervation along PC dendrites, the maximal CF extent from the top of the PC soma was calculated relative to the molecular layer thickness. All images were analyzed by MetaMorph software (Universal Imaging) and Image software.

Electron microscopy. Anesthetized mice were intracardially fixed with $2.0 \%$ paraformaldehyde and $2.5 \%$ glutaraldehyde in $0.1 \mathrm{M}$ phosphate buffer, pH 7.4. Brain slices $(1.0 \mathrm{~mm})$ prepared with a microslicer were postfixed in $1.0 \%$ osmium tetroxide, dehydrated, and then embedded in epoxy resin. Ultrathin sections were cut with an ultramicrotome, stained with uranyl acetate and lead citrate, and observed under a transmission electron microscope (1200EX; JEOL). For quantitative analysis, images were analyzed using Photoshop 7.0 (Adobe Systems) and ImageJ software.

Electrophysiology. For electrophysiological experiments, 9- to 10-week-old Itpr flox/flox and L7-Cre;Itpr $1^{\text {flox/flox }}$ mice were used. Cerebellar slices were prepared and whole-cell patchclamp recordings from PCs were made as described previously (Le et al., 2010). Under ether anesthesia, mice were decapitated and the cerebellum was excised. Sagittal cerebellar slices (300 $\mu \mathrm{m}$ thickness) were prepared from the vermis using a Vibratome tissue slicer (DTK1000; Dosaka EM) in $1 \mu \mathrm{M}$ tetrodotoxin (Wako Pure Chemical Industries Ltd.) that contained saline and were kept at room temperature (23$25^{\circ} \mathrm{C}$ ) for at least $1 \mathrm{~h}$ in normal saline. The recording chamber was perfused with standard Krebs-Henseleit Ringer's solution containing (in mM) $118 \mathrm{NaCl}, 4.7 \mathrm{KCl}, 2.5 \mathrm{CaCl}_{2}, 25.0$ $\mathrm{NaHCO}_{3}, 1.18 \mathrm{KH}_{2} \mathrm{PO}_{4}, 1.19 \mathrm{MgSO}_{4}$, and 11.0 glucose, which was added with $100 \mu \mathrm{M}$ picrotoxin, equilibrated with $95 \% \mathrm{O}_{2}$ and $5 \% \mathrm{CO}_{2}$ gas, and warmed to maintain the temperature of the perfusion chamber at $30-31^{\circ} \mathrm{C}$. Under an upright microscope, a whole-cell clamp pipette (resistance, 3-4 M $\Omega$ ) was attached to the soma of a PC located in anterior lobule. The pipette contained (in $\mathrm{mm}$ ) $134 \mathrm{~K}$-gluconate, 6 $\mathrm{KCl}, 4 \mathrm{NaCl}, 10$ HEPES, 0.2 EGTA, 4 MgATP, 0.3 Tris-GTP, and 14 phosphocreatine, $\mathrm{pH}$ 7.25. A Multiclamp700A amplifier and pClamp 9 software (Molecular Devices) were used. In experiments on the inputoutput relationship of PF-EPSPs, the stimulation pipette was placed on the molecular layer at a distance of $150 \mu \mathrm{m}$ from PC soma and $5 \mu \mathrm{m}$ in depth from the slice surface. The stimulus intensity threshold (T) was determined when the peak of EPSP was positive (after subtracting the base noise). Then, an input-output curve was recorded by gradually increasing the stimulus intensity $(1-5 \mathrm{~T})$. The paired-pulse facilitation (PPF) ratio was determined as the rising slope of the second PF-EPSP divided by that of the first PF-EPSP at interpulse intervals of $50 \mathrm{~ms}$. In the LTD sessions, we used two different LTD induction protocols. The first conjunctive stimulation consisting of single CF stimulation $(0.1 \mathrm{~ms}$ in duration) and double-pulse PF stimulation (each $0.1 \mathrm{~ms}$ in duration) 
paired at $50 \mathrm{~ms}$ intervals timed in such a way that the second pulse fell at the same time as the CF stimulation. The second conjunctive stimulation consisted of a current pulse-induced membrane depolarization $(200 \mathrm{~ms}$, within $2 \mathrm{nA}$ ) and a double-shock PF stimulation timed in such a way that the first pulse fell $30 \mathrm{~ms}$ after the onset of each depolarizing pulse. The conjunctive stimulation was repeated at $1 \mathrm{~Hz}$ for $5 \mathrm{~min}$ (300 pulses) in each trial of LTD induction.

Vestibulo-ocular reflex and optokinetic response eye movements. Eye movement was measured by the infra-red TV method as described previously (Katoh et al., 1998; Shutoh et al., 2006). Under isofluorane (Escain; Mylan) anesthesia and aseptic conditions, a platform for head fixation was made on the mouse cranial bone by synthetic resin (SuperBond C\&B; Sun Medical) and one 15-mm-long stainless bolt. Two days after surgery, a mouse was mounted on the turntable surrounded by a checked-pattern (check-size, $4^{\circ}$ ) screen (diameter, $60 \mathrm{~cm}$; height, $60 \mathrm{~cm}$ ), with the head fixed and the body loosely strained in a plastic cylinder. Two types of reflex eye movements, i.e., the horizontal vestibulo-ocular reflex (HVOR) and horizontal optokinetic response (HOKR), were measured. The HOKR was tested with the sinusoidal screen oscillation by $10-20^{\circ}$ (peak to peak) at $0.11-0.33 \mathrm{~Hz}$ (maximum screen velocity, 3.5$10.5 \%$ s) on the same plane in the light. The HVOR was tested by sinusoidal turntable oscillation (frequency, 0.11-0.5 Hz; peak-to-peak amplitude, $10^{\circ}$ ) on the plane in parallel with the bilateral horizontal semicircular canals in the dark. More than 10 cycles of the evoked eye movements that were free from artifacts due to blinks and saccades were averaged, and the mean amplitude and phase were calculated by a modified Fourier analysis (Jastreboff, 1979). The gain of the eye movement was defined as the ratio of the peak-to-peak amplitude of eye movements to that of the turntable or screen oscillation. The phase was defined as $0^{\circ}$ when the peak of the eye movement was opposite to the peak of turntable oscillation in the HVOR and when the peak of the eye movement matched the screen oscillation in the HOKR. To induce the adaptation of HOKR, the mice were trained to view 600 cycles of $0.16 \mathrm{~Hz}$ at $15^{\circ}$ screen oscillation continuously for $1 \mathrm{~h}$. The HOKR gains were measured by 50 cycles of oscillation at the start and end of $1 \mathrm{~h}$ of training.

Statistical analysis. All data were shown as the mean \pm SEM, and statistical significance was defined as $p<0.05$, as determined using the paired Student's $t$ test, the Mann-Whitney $U$ test, or a two-way ANOVA multiple measurements. Correlation analysis was performed using the nonparametric Spearman test.

\section{Results}

\section{Severe cerebellar ataxia in adult $\mathrm{L7}$-Cre;Itpr flox/flox $^{\text {mice }}$}

To establish PC-specific IP ${ }_{3} \mathrm{R} 1$ knock-out mice (L7-Cre; Itpr f floxflox $)$, we generated Itpr $1^{f l o x}$ mice (Fig. $1 A-C$; see Materials and Methods) and crossed them with transgenic mice expressing Cre recombinase under control of the L7 promoter (Barski et al., 2000). L7-Cre; Itpr $r^{f l o x}$ flox mice were born in the expected Mendelian ratios. In contrast to $\mathrm{IP}_{3} \mathrm{R} 1-$ null mice that died around postnatal day 21 (P21; Matsumoto et al., 1996), L7-Cre; Itpr $1^{\text {flox/flox }}$ mice could survive to adulthood. They displayed cerebellar ataxia beginning $\sim 6$ weeks after birth $(6 \mathrm{~W})$, which worsened as they continued to develop; they exhibited severe ataxia, and their footprints were not visibly discernible after 8W (Fig. 1D). Quantitative analysis of footprint patterns for stride length (Fig. $1 E$ ) and base width (Fig. $1 F$ ) clearly revealed the age-dependent onset and worsening of ataxia in L7-Cre; Itpr floxfflox mice. Although $\mathrm{IP}_{3} \mathrm{R} 1$-null mice presented seizure-like movements, such as opisthotonus (Matsumoto et al., 1996), L7-Cre;Itpr floxfflox mice did not.

We examined $\mathrm{IP}_{3} \mathrm{R} 1$ protein levels in the brain of $L 7$-Cre; Itpr fllox/flox mice at $10 \mathrm{~W}$ using immunohistochemistry and found that the $\mathrm{IP}_{3} \mathrm{R} 1$ signal was abolished in PCs, but not in other brain regions such as the cerebral cortex and hippocampus (Fig. 2A). Immunoblot analyses also revealed that $\mathrm{IP}_{3} \mathrm{R} 1$ expression levels were decreased in the cerebellum, but not in the cerebral cortex, of L7-Cre; Itpr $1^{\text {floxfflox }}$ mice at $8 \mathrm{~W}$ (Fig. 2B). The low level of $\mathrm{IP}_{3} \mathrm{R} 1$ protein in the cerebellum of L7-Cre;Itpr $1^{\text {flox/flox }}$ mice was detectable after long exposure times, which may be attributable to the residual expression of $\mathrm{IP}_{3} \mathrm{R} 1$ in a small number of PCs and to the presence of $\mathrm{IP}_{3} \mathrm{R} 1$ protein in GCs (Hisatsune et al., 2006).

It has been reported that the $\mathrm{L} 7$-Cre transgenic mice we used in this study started to exhibit the Cre-mediated recombination in a few PCs from P6, and it progressed in most PCs until P21 (Barski et al., 2000). To determine the interaction between the time course of $\mathrm{IP}_{3} \mathrm{R} 1$ deletion in PCs and the onset of ataxia during development, we examined the expression level of $\mathrm{IP}_{3} \mathrm{R} 1$

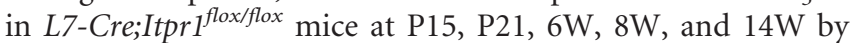
immunohistochemistry. As shown in Figure $2 \mathrm{C}$, the $\mathrm{IP}_{3} \mathrm{R} 1$ signal was strongly detected in most PCs at P15 and P21 ( $\sim 80 \%)$, but the number of $\mathrm{IP}_{3} \mathrm{R} 1$-positive PCs in L7-Cre;Itpr $1^{\text {flox/flox }}$ mice was dramatically decreased at $6 \mathrm{~W}(<25 \%)$ and abolished by $8 \mathrm{~W}$ $(<5 \%$; Fig. $2 C)$. The recombination efficiency of Itpr $r^{\text {flox }}$ allele by Cre recombinase and/or protein turnover of $\mathrm{IP}_{3} \mathrm{R} 1$ might be responsible for the time lag of $\mathrm{IP}_{3} \mathrm{R} 1$ deletion to the expression of Cre recombinase. Since cerebellar ataxia began in L7-Cre; Itpr $1^{f l o x}{ }^{\text {flox }}$ mice around $6 \mathrm{~W}$ (Fig. $1 D-F$ ), the result suggests that the onset of ataxia is associated with the deletion of $\mathrm{IP}_{3} \mathrm{R} 1$ protein in PCs.

\section{Abnormal maintenance of PC spine and dendritic morphology in adult L7-Cre;Itpr $1^{\text {floxfllox }}$ mice}

Although cerebellar degeneration is associated with many forms of hereditary ataxia (Dueñas et al., 2006), Nissl staining revealed that L7-Cre;Itpr $1^{f l o x / f l o x}$ mice had normal overall cerebellar morphology, including the organization of the cortical layer at $10 \mathrm{~W}$ (Fig. 2D). The cerebellar sizes in L7-Cre;Itpr f flox/flox mice were comparable to those of age-matched control Itpr $1^{\text {flox } f \text { flox }}$ mice at $10 \mathrm{~W}$, as assessed by normalization to longitudinal size in the cerebral cortex (cerebellum/cerebrum ratio: Itpr $1^{\text {floxfllox }}$ mice, $0.491 \pm 0.029 ;$ L7-Cre; Itpr $1^{\text {flox/flox }}$ mice, $0.458 \pm 0.027 ; n=5$ mice; $p=0.41, t$ test; Fig. $2 D$ ). Immunostaining for calbindin, which is a marker of $\mathrm{PC}$, revealed that the molecular layer thickness of $L 7$-Cre; Itpr $1^{\text {flox/flox }}$ mice was thinner than that of Itpr f $^{\text {flox/flox }}$ mice at 10W (Itpr $1^{\text {flox/flox }}, 148.6 \pm 1.9 \mu \mathrm{m} ;$ L7-Cre; Itpr $^{\text {floxfflox }}, 140.7 \pm 1.5$ $\mu \mathrm{m} ; n=3$ mice; $p<0.001$, Mann-Whitney $U$ test; Fig. $2 E)$. In addition, the PC soma area of L7-Cre;Itpr $1^{\text {flox flox }}$ mice was smaller than those of Itpr $r^{\text {flox flox }}$ mice (Itpr $r^{\text {flox flox }}, 285.4 \pm 5.2 \mu \mathrm{m}^{2}, n=54$ cells from three mice; $L 7$-Cre; Itpr f flox/flox $, 225.7 \pm 4.7 \mu \mathrm{m}^{2}, n=56$ cells from three mice; $p<0.0001, t$ test; Fig. 2E). However, apparent degeneration of PCs was not observed in L7-Cre; Itpr $1^{\text {flox fllox }}$ mice at 10W; PC density was comparable between Itpr $1^{\text {flox/flox }}$ and $L 7-C r e$; Itpr $r^{\text {flox flox }}$ mice $\left(I t p r 1^{\text {flox/flox }}, 3.82 \pm 0.15\right.$ cells $/ 100 \mu \mathrm{m} ;$ L7-Cre; Itpr $^{\text {flox/flox }}, 4.00 \pm 0.12$ cells $/ 100 \mu \mathrm{m} ; n=3$ mice; $p=0.37, t$ test; Fig. 2E).

To further investigate the precise morphology of individual PCs in adult L7-Cre;Itpr f flox/flox mice, neurons were visualized by Golgi staining. PCs from Itpr $1^{\text {flox/flox }}$ mice displayed well developed dendritic arbors, whereas PCs from L7-Cre; Itpr $1^{\text {flox fllox mice }}$ had $\sim 40 \%$ fewer dendritic branching points than those from Itpr fllox/flox mice at 10W (Itpri flox/flox: $232.2 \pm 10.8 /$ cell, $n=11$ neurons from two mice; L7-Cre;Itpr flloxfflox: $140.8 \pm 6.5$ /cell, $n=$ 13 neurons from two mice; $p<0.0001, t$ test; Fig. $3 A$ ). Interestingly, a closer examination revealed the striking increase in the spine density of PCs in the L7-Cre; Itpr $1^{\text {flox/flox }}$ mice (Fig. 3B). This increased spine density was apparent in the distal dendritic region of PCs, but not in the proximal region.

To quantify the spine abnormalities of PCs in L7-Cre; Itpr $1^{\text {flox/flox }}$ mice, we crossed L7-Cre;Itpr $1^{f l o x}{ }^{f f l o x}$ mice with Pcp2-GFP mice expressing GFP in the PCs (Tomomura et al., 2001), resulting in L7-

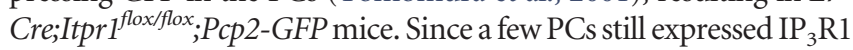


in the adult L7-Cre; Itpr $1^{\text {flox/flox }}$ mice, we immunostained the $\mathrm{IP}_{3} \mathrm{R} 1$ of $\mathrm{PCs}$ and assessed the relationship between $\mathrm{IP}_{3} \mathrm{R} 1$ expression and $\mathrm{PC}$ spine density. As shown in Figure $3 C$, an abnormal increase of spine density was clearly observed in the $\mathrm{IP}_{3} \mathrm{R} 1$-negative $\mathrm{PCs}$, but not in the IP ${ }_{3} \mathrm{R} 1$-positive PCs of $L 7$-Cre; Itpr $1^{\text {flox/flox }} ;$ P $C$ 2-GFP mice at $10 \mathrm{~W}$ (Fig. $3 C$ ), and we found a negative correlation between $\mathrm{IP}_{3} \mathrm{R} 1$ expression levels and spine densities (Fig. 3D). Spine densities along distal dendrites of the L7-Cre; Itpr $1^{\text {flox/flox }} ;$ Pcp2-GFP PCs increased to $143 \%$ of those of control Itpr $1^{\text {flox/flox }} ;$ Pcp2-GFP PCs (Itpr1 $1^{\text {flox/flox }}$; Pcp2-GFP, $2.402 \pm 0.096$ spines/ $\mu \mathrm{m} ;$ L7-Cre;Itpr1 ${ }^{\text {flox/flox }} ;$ Pcp2-GFP, $3.436 \pm 0.109$ spines/ $\mu \mathrm{m} ; n=17$ neurons from two mice; $p<$ $0.0001, t$ test; Fig. $3 E$ ). In addition, the spine length of the L7-Cre; Itpr ${ }^{\text {flox/flox }}$;Pcp2-GFP PCs appeared to be longer than that of the control PCs (Itpr1 ${ }_{\text {flox/flox }}$ Pcp2-GFP, $0.898 \pm 0.018 \mu \mathrm{m}, n=230$ spines from two mice; L7-Cre; Itpr $1^{\text {flox/flox }} ;$ Pcp2-GFP, $1.174 \pm 0.027$ $\mu \mathrm{m}, n=231$ spines from two mice; $p<0.0001$, Mann-Whitney $U$ test). In contrast, spine head diameter was not significantly different between $L 7-C r e$; Itpr $1^{\text {flox/flox }}$;Pcp2-GFP and control PCs (Itpr1 ${ }^{\text {flox/flox }}$; Pcp2-GFP, $0.542 \pm 0.011 \mu \mathrm{m}, n=230$ spines from two mice; $L 7-$ Cre;Itpr1 ${ }^{\text {flox/flox }}$;Pcp2-GFP, $0.544 \pm 0.010 \mu \mathrm{m}, n=231$ spines from two mice; $p=0.9, t$ test). The spine density was also not changed at the proximal dendrites in the L7-Cre;Itpr $1^{\text {flox/flox }}$;Pcp2-GFP PCs.

PC dendritic outgrowth and formation of synapses with PFs and CFs have been shown to occur extensively during the first 3 postnatal weeks (Sotelo and Dusart, 2009; Tanaka, 2009). To examine whether abnormal dendritic development and spinogenesis during this developmental period was responsible for dendritic and spine abnormalities of adult L7-Cre;Itpr $1^{\text {flox/flox }}$ mice, we examined the morphology of PCs in L7-Cre;Itpr $1^{\text {flox/flox }}$ mice at $3 \mathrm{~W}$. Golgi staining revealed that the apparent PC dendritic morphology was comparable between control and L7-Cre; Itpr $1^{\text {flox/flox }}$ mice at $3 \mathrm{~W}$ (branching point; Itpr $f^{\text {flox/flox }}, 211.3 \pm$ 9.9/cell; L7-Cre;Itpr1 flox/flox, $204.3 \pm 13.1 /$ cell; $n=10$ neurons from two mice; $p=0.67, t$ test). We also could not observe any significant changes in spine density, length, and head diameter between $L 7$-Cre; Itpr $1^{\text {flox/flox }}$;Pcp2-GFP mice and age-matched control Itpr $1^{\text {flox/flox }}$;Pcp2-GFP mice at $3 \mathrm{~W}$ (spine density: Itpr $1^{\text {flox/flox }} ; P c p 2-$ GFP, $2.488 \pm 0.070$ spines $/ \mu \mathrm{m}, n=20$ neurons from two mice; L7-Cre;Itpr $1^{\text {flox/flox }} ;$ Pcp2-GFP, $2.448 \pm 0.087$ spines $/ \mu \mathrm{m}, n=28$ neurons from two mice; $p=0.74, t$ test; spine length: Itpr $1^{\text {flox/flox }} ; P c p 2-$ GFP, $0.761 \pm 0.012 \mu \mathrm{m}, n=402$ spines from two mice; L7-Cre; Itpr $1^{\text {flox/flox }} ; P c p 2-G F P, 0.733 \pm 0.010 \mu \mathrm{m}, n=541$ spines from two mice; $p=0.07, t$ test; spine head diameter: Itpr $1^{\text {flox/flox }} ; P c p 2-G F P$, $0.470 \pm 0.008 \mu \mathrm{m}, n=402$ spines from two mice; L7-Cre; Itpr $1^{\text {flox/flox }} ;$ Pcp2-GFP, $0.485 \pm 0.007 \mu \mathrm{m}, n=541$ spines from two mice; $p=0.45$, Mann-Whitney $U$ test).

Because most PCs in L7-Cre;Itpr1 ${ }^{\text {flox/flox }} ;$ Pcp2-GFP mice expressed $\mathrm{IP}_{3} \mathrm{R} 1$ at $3 \mathrm{~W}$ (Fig. $2 \mathrm{C}$ ), we further assessed the relationship between $\mathrm{IP}_{3} \mathrm{R} 1$ expression levels and spine density of PCs in

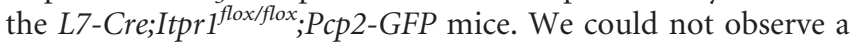
correlation between $\mathrm{IP}_{3} \mathrm{R} 1$ expression levels and spine densities ( $n=26$ neurons from two mice; $r=0.246, p=0.22$, Spearman correlation), indicating that $\mathrm{PC} \mathrm{IP} \mathrm{I}_{3} \mathrm{R} 1$ was not essential for spine development. Together, these results suggest that $\mathrm{IP}_{3} \mathrm{R} 1$ in $\mathrm{PCs}$ plays a crucial role in the maintenance of spines in the mature cerebellum.

Formation of functional PF-PC synapses in adult L7-Cre; Itpr $1^{\text {flox/flox }}$ mice

We next investigated whether abnormal spines observed in adult L7-Cre; Itpr $1^{\text {flox/flox }}$ mice form synapses with PF terminals. To this end, we stained presynaptic PF terminals with an anti-VGluT1 antibody and assessed the contact of GFP-labeled spines with the
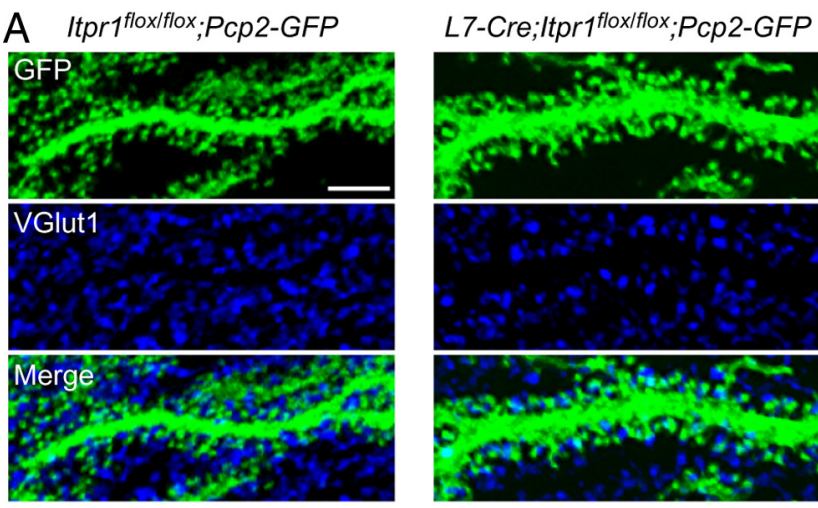

\section{B Itprifloxiflox}

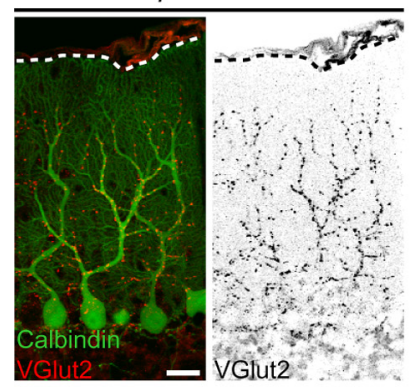

C Itprfflox/flox

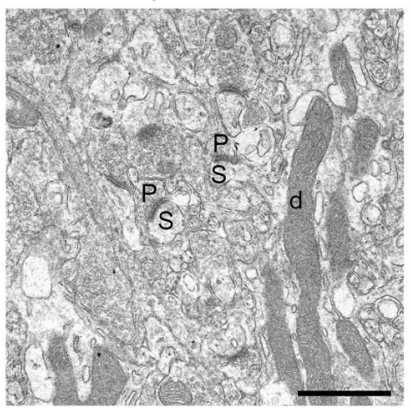

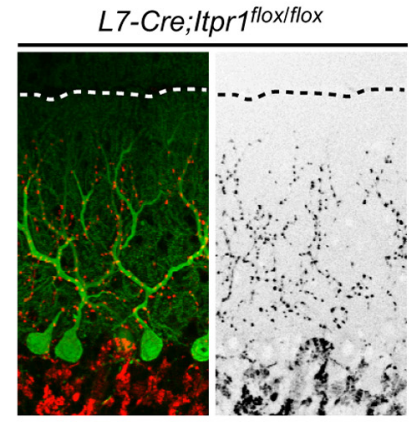

L7-Cre;Itpr1 flox/flox

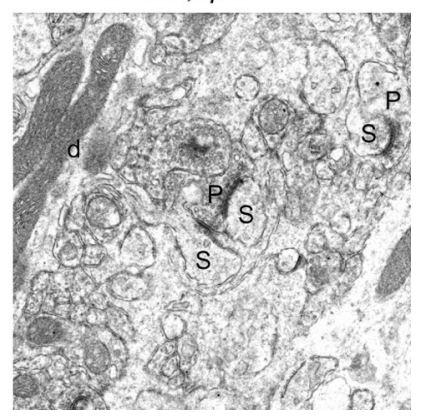

Figure 4. Formation of PF-PC and CF-PC synapses in adult L7-Cre;/tpr $7^{\text {flox/flox }}$ mice. A, Immuno-

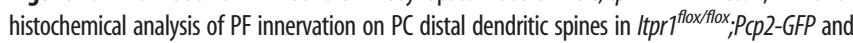

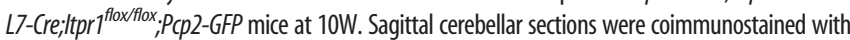
anti-GFP (green) and anti-VGluT1 antibodies (blue). Representative images of PC distal dendritic region are shown. Scale bar, $5 \mu \mathrm{m}$. $\boldsymbol{B}$, Immunohistochemical analysis of CF innervation on PCs in

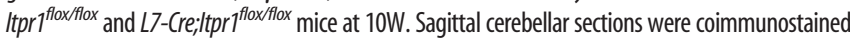
with anti-calbindin (green) and anti-VGluT2 antibodies (red). Representative images are shown. Dotted lines indicate the pial surface. Scale bar, $20 \mu \mathrm{m}$. C, Ultrastructure of the molecular layer of the cerebellum in $/$ tpr $7^{\text {flox/flox }}$ and L7-Cre;/tpr $7^{\text {flox/flox }}$ mice at 10W. Spines containing PSD (S), PF presynaptic terminals containing active zone and synaptic vesicles $(P)$, and $P($ dendrites $(d)$ are indicated. Scale bar, $1 \mu \mathrm{m}$.

VGluT1-labeled PF terminals in L7-Cre; Itpr1 ${ }^{\text {flox/flox }}$;Pcp2-GFP mice at 10W (Fig. 4A). The mean percentage of spines that were in contact with PF terminals was comparable between $L 7-C r e$;

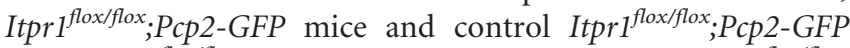
mice (Itpr1 ${ }^{\text {flox/flox }} ;$ Pcp2-GFP, $86.9 \pm 2.1 \%$; L7-Cre; Itpr $1^{\text {flox/flox }}$; Pcp2-GFP, $88.4 \pm 2.0 \% ; n=12$ neurons from three mice; $p=$ $0.62, t$ test), suggesting that abnormally formed PC spines were able to make synapses with PF terminals in adult L7-Cre; Itpr $1^{\text {flox/flox }}$ mice.

To examine the distribution patterns of CF terminals-another type of excitatory projection to PCs-in the molecular layer of adult L7-Cre; Itpr $1^{\text {flox/flox }}$ mice, presynaptic CF terminals were immunostained with an anti-VGluT2 antibody. As shown in Fig- 
ure $4 B$, there was no obvious difference in the distribution pattern of VGluT2-immunoreactive puncta between L7-Cre; Itpr flox/flox and control Itpri flox/flox mice at 10W (Fig. 4B). The extent of CF innervation along the PC dendrites, quantified as the relative height of VGluT2 puncta to the molecular layer thickness, was not significantly different between the L7-Cre; Itpr flox/flox $^{\text {and the Itpr } 1^{\text {flox/flox }} \text { mice (Itpr flox/flox }}, 0.832 \pm 0.006$; L7-Cre; Itpr1 $1^{\text {flox/flox }}, 0.831 \pm 0.004 ; n=3$ mice; $p=0.60$, MannWhitney $U$ test). These data indicate that the innervation of PCs by CFs in adult L7-Cre; Itpr $1^{\text {flox/flox }}$ mice was comparable to that in Itpr $1^{\text {flox/flox }}$ mice.

We also performed a transmission electron microscopy analysis to visualize synaptic ultrastructure (Fig. 4C). Consistent with the immunohistochemical analysis result, free spines-spines without any attached PF terminals (Guastavino et al., 1990; Kurihara et al., 1997) — were rarely seen in L7-Cre; Itpr $1^{\text {flox/flox }}$ mice at $10 \mathrm{~W}$, similar to controls (percentage of spines contacted with PF terminals: Itpr1 flox/flox, $99.4 \pm 0.4 \%$; L7-Cre; Itpr1 $1^{\text {flox/flox }}, 98.8 \pm$ $0.9 \% ; n=12$ sections from two mice; $p=0.86$, Mann-Whitney $U$ test). In addition, almost all spines formed synapses with PF terminals in a one-to-one fashion, and spines contacting two or more synaptic terminals were not observed in either Itpr $1^{\text {flox/flox }}$ or L7-Cre;Itpr $1^{\text {flox/flox }}$ PCs (percentage of multiple synapse: Itpr flox/flox $^{\text {flo }} 0.030 \pm 0.011 \%, n=396$ synapses from two mice; L7-Cre; Itpr1 $1^{\text {flox/flox }}, 0.041 \pm 0.009 \%, n=249$ synapses from two mice; $p=0.44, t$ test). Although abnormal enlargement of PF presynaptic terminals and vesicle accumulation have been reported in $\mathrm{IP}_{3} \mathrm{R} 1$-null mice (Hisatsune et al., 2006), the L7-Cre; Itpr flox/flox mice did not show these abnormalities in PF-PC synapses (PF presynaptic area: Itpr $1^{\text {flox/flox }}, 0.281 \pm 0.012 \mu \mathrm{m}^{2}$, 167 synapses from two mice; L7-Cre; Itpri flox/flox, $0.284 \pm 0.013$ $\mu \mathrm{m}^{2}, n=150$ synapses from two mice; $p=0.90, t$ test; PF presynaptic vesicle density: Itpr $1^{\text {flox/flox }}, 102.8 \pm 2.8$ vesicles $/ \mu \mathrm{m}^{2}, 72$ synapses from two mice; L7-Cre; Itpr $1^{\text {flox/flox }}, 101.1 \pm 3.9$ vesicles/ $\mu \mathrm{m}^{2}, n=61$ synapses from two mice; $p=0.71, t$ test).

To further examine whether the PF-PC synapses of adult L7Cre; Itpr $1^{\text {flox/flox }}$ mice were functional, we compared the inputoutput relationship of PF-EPSP amplitudes of PCs in acute cerebellar slices by using the whole-cell patch-clamp method. We found that PCs of L7-Cre; Itpr $1^{\text {flox/flox }}$ mice at 10W displayed significantly larger PF-EPSPs than age-matched Itpr flox/flox mice (Fig. 5A). We also assessed the probability of presynaptic transmitter release by measuring the PPF of the PF-EPSPs, and found that the PPF ratio at interpulse intervals of $50 \mathrm{~ms}$ was comparable between L7-Cre;Itpr $1^{\text {flox/flox }}$ and control Itpr $1^{\text {flox/flox }}$ mice at $10 \mathrm{~W}$ (Itpr1 flox/flox $1.353 \pm 0.028, n=15$ cells from 10 mice; L7-Cre; Itpr flox/flox $^{\text {f }} 1.363 \pm 0.019, n=22$ cells from 11 mice; $p=0.77, t$ test; Fig. $5 B$ ), indicating that the large PF-EPSPs of the inputoutput relationship in the L7-Cre; Itpr $1^{\text {flox/flox }}$ mice could not be dependent on PF presynaptic effect. These results suggest that abnormally increased synapses formed on the distal dendrites of L7-Cre; Itpr $1^{\text {flox/flox }}$ PCs are functional, and that functional synapse density in the stimulated region increases in L7-Cre; Itpr $f^{\text {flox/flox }}$ mice at $10 \mathrm{~W}$. Together, these findings suggest that abnormal spines of PCs form functional synapses with PF in adult L7-Cre; Itpr1 ${ }^{\text {flox/flox }}$ mice.

\section{Impaired cerebellar LTD and motor learning in adult L7-Cre;} Itpr $1^{\text {flox/flox }}$ mice

PF-PC synapses are sites where cerebellar LTD is induced by a simultaneous activation of PFs and CFs, and these are known to be involved in certain types of motor learning (Ito, 1989). We previously showed that $\mathrm{IP}_{3} \mathrm{R} 1$ plays an essential role in the induc-

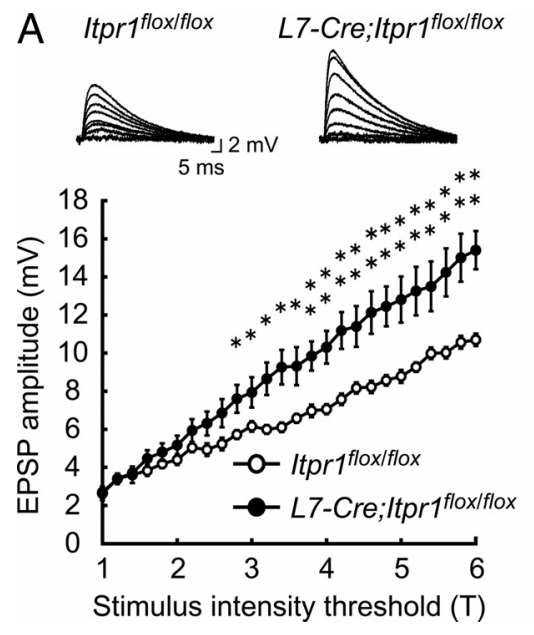

B
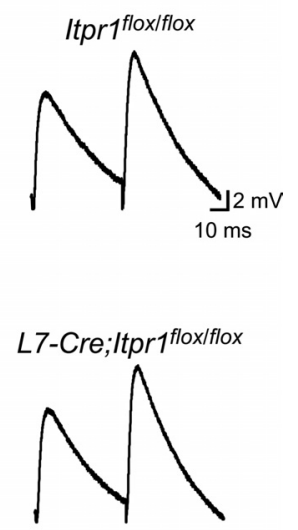

Figure 5. Formation of functional PF-PC synapse in adult L7-Cre;/tpr $7^{\text {flox/flox }}$ mice. A, Averaged input- output relationship of PF-EPSPs in acute cerebellar slices from 9- to 10-week-old Itpr $7^{\text {flox/flox }}$ and L7-Cre;/tpr $7^{\text {flox/flox }}$ mice. Plot of EPSP amplitude versus the T from Itpr $7^{\text {flox/flox }}$ (white circles) and L7-Cre;/tpr $7^{\text {flox/flox }}$ (black circles) mice are shown (Itpr flox/flox,$n=6$ neurons from three mice; L7-Cre;/tpr $7^{\text {flox/flox }}, n=8$ neurons from three mice; ${ }^{*} p<0.05,{ }^{* *} p<0.01, t$ test). Insets show representative EPSP traces evoked by PF stimuli of different intensities. $\boldsymbol{B}$, The PPF ratio of the PF-EPSPs from acute cerebellar slices from 9- to 10-week-old Itpr $7^{\text {flox/flox }}$ or

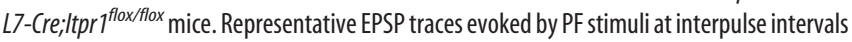
of $50 \mathrm{~ms}$ are shown.

tion of cerebellar LTD by using $\mathrm{IP}_{3} \mathrm{R} 1$-null mice (Inoue et al., 1998). Therefore, we examined whether $I_{3} R 1$ in PCs was necessary for the induction of LTD by using 9- to 10-week-old L7-Cre; Itpr $1^{\text {flox/flox }}$ mice. As shown in Figure $6 A$, conjunctive stimulation of PF and CF induced LTD of PF-EPSPs in acute cerebellar slices obtained from the Itpriflox/flox mice. In contrast, in the L7-Cre; Itpr $1^{\text {flox/flox }}$ mice, induction of LTD was blocked (Fig. 6A). We also used another LTD-induction protocol that replaced CF stimulation with direct depolarization of PCs to exclude any effect from CF properties. This protocol also induced LTD in the

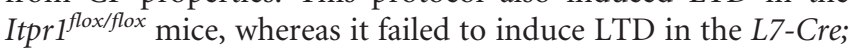
Itpr $1^{\text {flox/flox }}$ mice (Fig. 6B).

Finally, to evaluate the motor learning ability of adult $\mathrm{L7}$-Cre; Itpr $1^{\text {flox/flox }}$ mice, we tested the adaptation of the HOKR, which is a simple form of cerebellar motor learning (Katoh et al., 1998, 2000). Since the cerebellar flocculus is an essential site for HOKR adaptation (Katoh et al., 1998), we first assessed the expression level of $\mathrm{IP}_{3} \mathrm{R} 1$ in floccular PCs and found that most $\mathrm{L7}-\mathrm{Cre}$; Itpr $1^{\text {flox/flox }} \mathrm{PCs}$ lacked $\mathrm{IP}_{3} \mathrm{R} 1$ expression at $10 \mathrm{~W}$ (Fig. $7 A$ ). In addition, the L7-Cre; Itpr $1^{\text {flox/flox }}$ mice displayed no detectable loss of PCs or other cells in the flocculus and had normal overall flocculus morphologies (Fig. $7 A, B$ ).

We next investigated the basic properties of the HOKR and HVOR, which are eye movements that compensate for the movements of the visual field and head, respectively, to assess the dynamic characteristics of eye movements in L7-Cre; Itpr flox/flox mice at $10 \mathrm{~W}$. We characterized the amplitude and temporal properties of eye movements by the gain and phase of the eye movement response. Gain is the ratio of the amplitude of eye movement to the amplitude of visual (HOKR) or head (HVOR) movement. Phase is a parameter described as the temporal relationship between eye movement and visual or head movement. During eye movement testing, spontaneous nystagmic movements were rarely seen in the L7-Cre; Itpr $1^{\text {flox/flox }}$ mice in both light and dark conditions. The HOKR gains (amplitude) of the L7-Cre; Itpri flox/flox mice were smaller than those of the control 

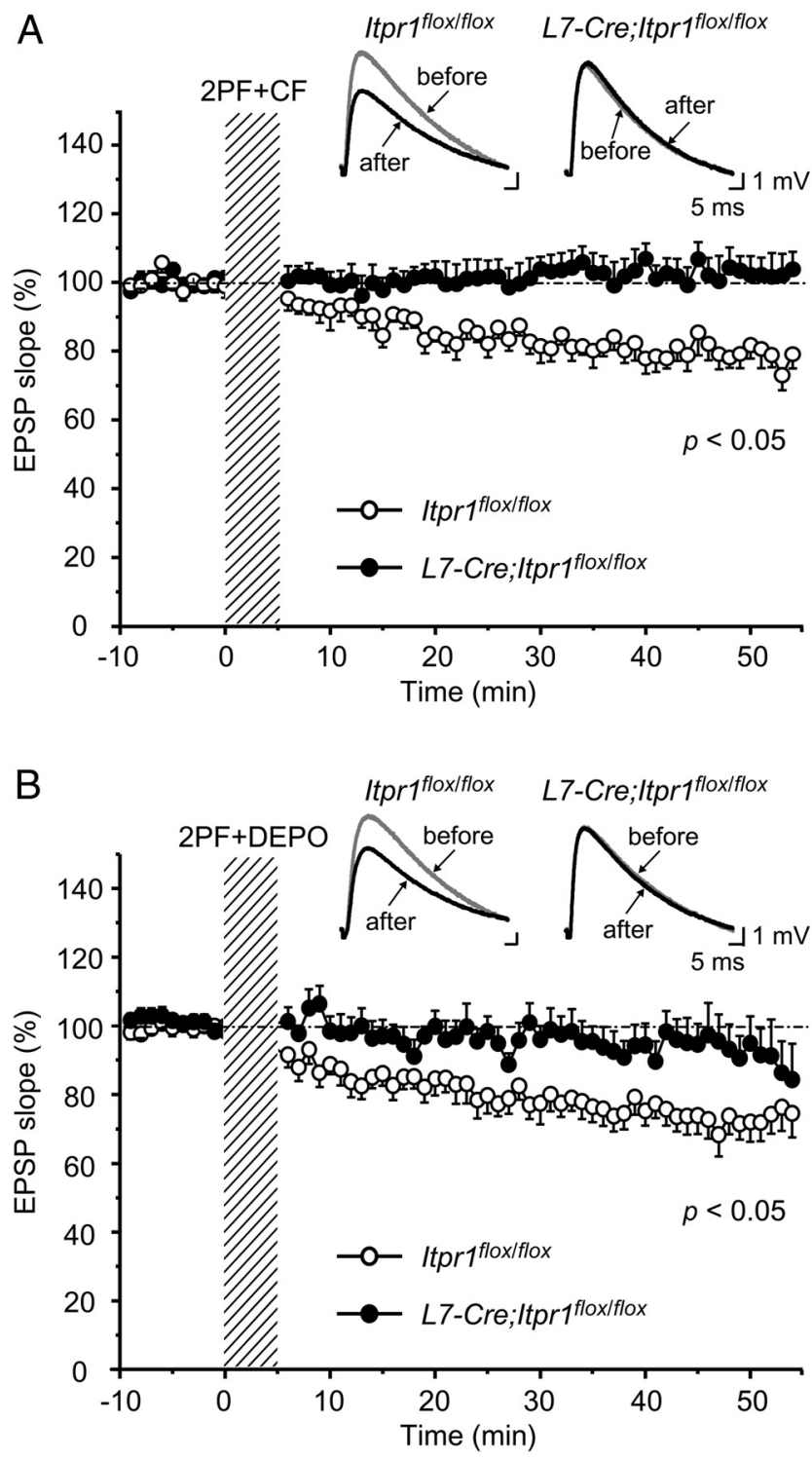

Figure 6. Lack of cerebellar LTD in L7-Cre;Itpr $7^{\text {flox/flox }}$ mice. A, Averaged time course of LTD induced by conjunctive stimulation of double-shock PF stimulation (2PF) and CF stimulation (CF) from Itpr $7^{\text {floxfflox }}$ (white circles) and L7-Cre;/Ipr $7^{\text {floxfflox }}$ (black circles) mice at 10W. Rising slopes of PF-EPSPs relative to average baseline values during the 5 min preconjunction period are shown. The obliquely shaded band indicates period of conjunction. LTD magnitude, the average decrease in PF-EPSP slopes at 41-50 min, was used for statistical analysis (Itpr floxfflox $^{\text {, }}$ $n=6$ neurons from four mice; $L 7$-Cre; Itpr $7^{\text {flox fllox }}, n=6$ neurons from six mice; $p<0.05, t$ test). Inset shows superimposed PF-EPSP traces recorded before (gray line) and after (black line) conjunctive stimulation. $\boldsymbol{B}$, Averaged time course of $L T D$ induced by conjunctive stimulation of 2PF and membrane depolarization (DEPO) from Itpr f $7^{\text {floxffox }}$ (white circles) and L7-Cre; Itpr $7^{\text {flox ffox }}$ (black circles) mice at 10W (Itpr $7^{\text {floxfflox }}, n=7$ neurons from six mice; L7-Cre; Itpr $7^{\text {flox fflox }}, n=6$ neurons from six mice; $p<0.05, t$ test). Inset shows superimposed PF-EPSP traces recorded before (gray line) and after (black line) conjunctive stimulation.

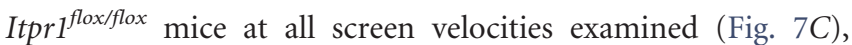
whereas the HOKR phases (timing) were similar to those of the Itpr $1^{\text {flox/flox }}$ mice (Itpr1 $1^{\text {flox/flox }}, n=13$ mice; L7-Cre;Itpr $1^{\text {flox/flox }}$, $n=5$ mice; $p=0.10$, two-way repeated-measures ANOVA). No significant changes were observed in the HVOR gains or phases between the Itpr $1^{\text {flox/flox }}$ and the L7-Cre; Itpr $1^{\text {flox flox }}$ mice (HVOR gain: Itpr $1^{\text {flox/flox }}, n=7$ mice; L7-Cre; Itpr $1^{\text {flox/flox }}, n=5$ mice; $p=$ 0.97, two-way repeated-measures ANOVA; HVOR phase: Itpr flox/flox $^{\text {flo }} n=7$ mice; L7-Cre; Itpr $1^{\text {flox/flox }}, n=5$ mice; $p=0.07$, two-way repeated-measures ANOVA).
Sustained exposure of the eyes to screen oscillations in the presence of sufficient retinal slips for $1 \mathrm{~h}$ induces adaptive changes in the HOKR gain in mice (Ito, 1989; Katoh et al., 1998). Ten-week-old Itpri $1^{\text {flox/flox }}$ mice demonstrated an adaptive increase in HOKR gain (delta gain) by 0.05 on average during $1 \mathrm{~h}$. In contrast, no adaptive increase in HOKR gain was observed in the L7-Cre; Itpr $1^{\text {flox/flox }}$ mice (Fig. 8A,B). These results indicate that $\mathrm{IP}_{3} \mathrm{R} 1$ in PCs is essential for the induction of PF-PC LTD and HOKR adaptation; this supports the hypothesis that PF-PC LTD underlies cerebellar motor learning (Ito, 1989; Yuzaki, 2012).

\section{Discussion}

In this study, we present two major findings. First, the loss of $\mathrm{IP}_{3} \mathrm{R} 1$ in PCs causes cerebellar dysfunction, motor discoordination, and impaired cerebellar learning and PF-PC LTD in adult L7-Cre; Itpr $1^{\text {flox/flox }}$ mice. Second, PC IP ${ }_{3} \mathrm{R} 1$ is critical for the maintenance of cerebellar synaptic circuits, especially the spatial arrangement of $\mathrm{PF}-\mathrm{PC}$ synapses in the mature cerebellar cortex.

$\mathrm{Ca}^{2+}$ influx through ligand-gated or voltage-gated $\mathrm{Ca}^{2+}$ channels and $\mathrm{Ca}^{2+}$ release from the ER are two major $\mathrm{Ca}^{2+}$ sources in spines; ryanodine receptors (RyRs) or $\mathrm{IP}_{3} \mathrm{Rs}$ are responsible for the latter. Interestingly, RyRs and $\mathrm{IP}_{3}$ Rs show distinct expression patterns in the spines of hippocampal neurons and PCs (Sharp et al., 1993): RyRs, but not $\mathrm{IP}_{3} \mathrm{Rs}$, are expressed in hippocampal neuron spines, whereas $\mathrm{IP}_{3} \mathrm{Rs}$, but not RyRs, are localized in the PC spines. Although it was previously reported that $\mathrm{Ca}^{2+}$ release from the ER through RyRs induced changes in spine morphology and the formation of new spines in cultured hippocampal neurons (Korkotian and Segal, 1999), the role of $\mathrm{IP}_{3} \mathrm{R} 1$ in controlling spine morphology was unclear. In this study, we provide the first evidence that loss of $\mathrm{IP}_{3} \mathrm{R} 1$ function produces an abnormal increase in spine density and length in mature PCs. Thus, our results suggest that the $\mathrm{IP}_{3} \mathrm{R}$ has a critical role in the regulation of spine distribution and morphology of adult PCs in vivo.

Although PCs in L7-Cre; Itpr $1^{\text {flox/flox }}$ mice have quite normal morphology at $3 \mathrm{~W}$, they display a dramatic increase in spine density and length along distal dendrites, and a decrease in dendritic branch points in adults. We previously reported that $\mathrm{IP}_{3} \mathrm{R} 1$-null mice had normal PC spine density at P20 but showed abnormal PC dendrites, which is caused by the absence of $\mathrm{IP}_{3} \mathrm{R} 1$ in GCs but not in PCs (Hisatsune et al., 2006). Therefore, the abnormal spine and dendritic morphology of the mature PCs in L7-Cre; Itpr $1^{\text {flox/flox }}$ mice is likely caused by defects in spine and dendritic morphology maintenance, rather than defects during neuronal development. Concerning normal spine morphogenesis in $\mathrm{IP}_{3} \mathrm{R} 1$-null mice, an alteration in the presynaptic function of the $\mathrm{PF}-\mathrm{PC}$ synapses was also observed in $\mathrm{IP}_{3} \mathrm{R} 1$-null mice $(\mathrm{Ma}-$ tsumoto et al., 1996; Hisatsune et al., 2006); consequently, there is a possibility that normal spine morphogenesis in PCs of $\mathrm{IP}_{3} \mathrm{R} 1$ null mice is due to alterations in PF presynaptic function. However, several studies using mice lacking GCs provide evidence that spinogenesis in the distal dendrites of PCs is intrinsic and not dependent on presynaptic axons (Mariani et al., 1975; Hirano et al., 1977; Sotelo, 1977). Thus, if $\mathrm{IP}_{3} \mathrm{R} 1$ in PCs is required for normal spinogenesis in developing PCs, spine abnormality is expected to occur in $\mathrm{IP}_{3} \mathrm{R} 1$-null mice. Together, we conclude that $\mathrm{IP}_{3} \mathrm{R} 1$ plays a critical role in the maintenance of spine and dendritic morphology in mature PCs.

Studies using mice lacking $\mathrm{IP}_{3} \mathrm{R} 1$ and other upstream molecules of $\mathrm{IP}_{3} \mathrm{R} 1$ in PCs (Aiba et al., 1994; Matsumoto et al., 1996; Kim et al., 1997; Offermanns et al., 1997; Kano et al., 1998; Ichise et al., 2000; Miyata et al., 2001; Nakao et al., 2007; Frederick et al., 
A
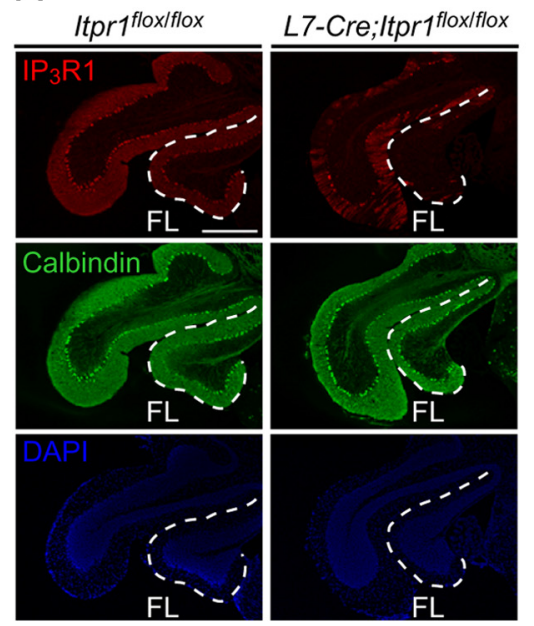

B

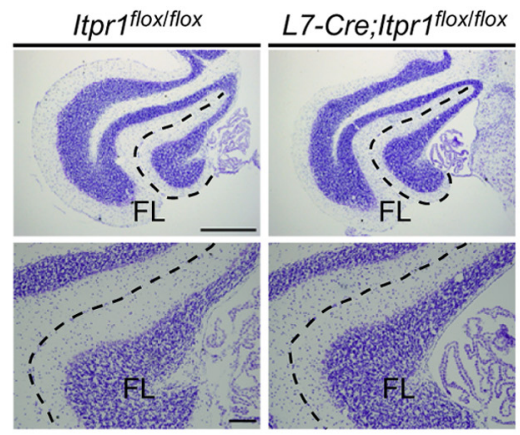

C

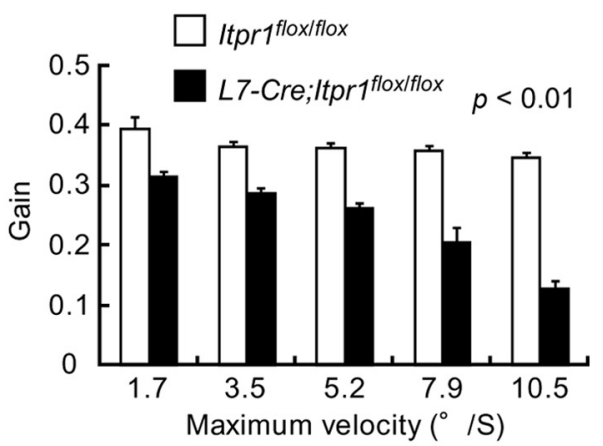

Figure 7. Characteristics of eye movements in $L 7-C r e ; I t p r 7^{\text {flox/flox }}$ mice. $A$, Immunohistochemical analysis of $I P_{3} R 1$ protein in the cerebellar flocculus (FL). Coronal sections prepared from Itpr $1^{\text {flox/flox }}$ and $L 7$-Cre;/tpr $1^{\text {flox/flox }}$ mice at 10 W were stained with anti-IP $\mathrm{R} 1$ (4C11, red) and anti-calbindin (green) antibodies and DAPI (blue). Scale bar, $500 \mu \mathrm{m}$. $\boldsymbol{B}$, NissI staining of coronal sections of cerebellar flocculus prepared from Itpr $7^{\text {flox/flox }}$ and L7-Cre;Itpr $7^{\text {flox/flox }}$ mice at $10 \mathrm{~W}$. Bottom panels show a magnified view of the top panels. Scale bars: top, $500 \mu \mathrm{m}$; bottom, $100 \mu \mathrm{m}$. C, HOKR gain of $/$ tpr $7^{\text {flox/flox }}$ (white bars) and $L 7-C r e, / t p r 7^{\text {flox/flox }}$ (black bars) mice at 10W. HOKR was measured by sinusoidal screen oscillation at 5-20 (peak-to-peak) and $0.11-0.17$ Hz (maximum screen velocity, $\left.2.6-10.5^{\circ} / \mathrm{s}\right)$ in the light (Itpr $7^{\text {flox/flox }}, n=13$ mice; $L 7$-Cre; Itpr $7^{\text {flox/flox }}, n=5$ mice; two-way repeated-measures ANOVA). $p$ value is shown in the panel.

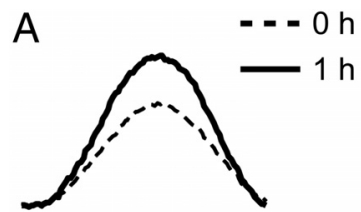

Itprfflox/flox

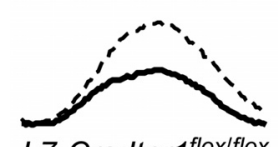

L7-Cre;Itpr1flox/flox

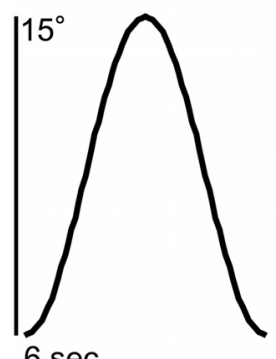

Screen
B

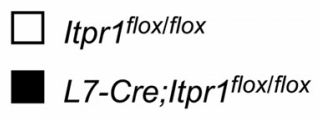

L7-Cre;Itpr1 flox/flox

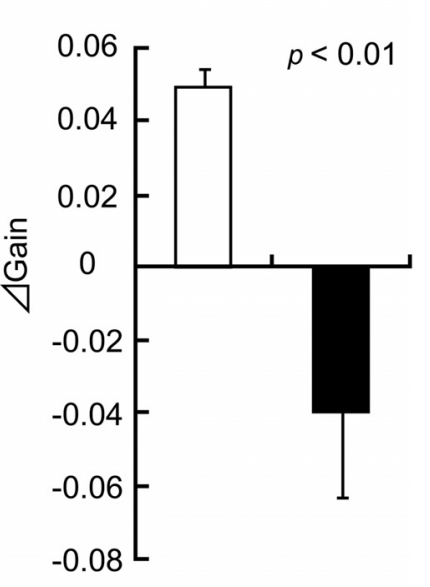

Figure 8. Lack of HOKR adaptation in L7-Cre;/tpr $7^{\text {flox/flox }}$ mice. $\boldsymbol{A}$, Examples of eye movement traces at $0 \mathrm{~h}$ (dashed lines) and after $1 \mathrm{~h}$ (solid lines) of sustained screen oscillation ( $15^{\circ}$ at 0.17

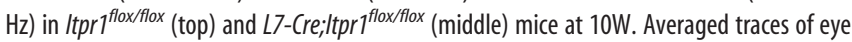
position obtained from $>10$ cycles of screen oscillation are shown. The trace of screen position is shown in the bottom panel. $\boldsymbol{B}$, The mean HOKR gain changes during $1 \mathrm{~h}$ of sustained screen oscillation of Itpr $7^{\text {flox/flox }}$ (white bar) and L7-Cre;/tpr $7^{\text {flox/flox }}$ (black bar) at 10W. HOKR gain change was defined as the HOKR gain at $1 \mathrm{~h}-$ HOKR gain at $0 \mathrm{~h}$ ( $n=7$ mice; Mann-Whitney $U$ test). $p$ value is shown in the panel.

2012) have suggested that type 1 metabotropic glutamate receptor (mGluR1)-heteromeric G-protein $\alpha$ q subunit (G $\alpha \mathrm{q})$ phospholipase C (PLC) $\beta 4-\mathrm{IP}_{3}-\mathrm{IP}_{3} \mathrm{R} 1$ signaling is essential for motor coordination. However, ataxia observed in L7-Cre; Itpr $1^{\text {flox/flox }}$ mice appeared to be more severe than that in other mutant mice, since mGluR1 or PLC $\beta 4$ knock-out mice were re- ported to present clear footprints (Kim et al., 1997; Ichise et al., 2000; Nakao et al., 2007). mGluR1, G $\alpha$ q, or PLC $\beta 4$ knock-out mice were able to perform the rota-rod test (Offermanns et al., 1997; Kano et al., 1998; Ichise et al., 2000; Miyata et al., 2001; Nakao et al., 2007; Frederick et al., 2012), but L7-Cre;Itpr $1^{\text {flox/flox }}$ mice older than $8 \mathrm{~W}$ could not even retain normal posture for the rota-rod test. Why did such unexpectedly severe ataxia occur in

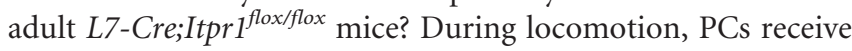
sensory and motor inputs through the mossy fiber-GC-PF pathway and integrate them to provide feedback to cerebellar nuclei (Arshavsky et al., 1983; Ito, 2002). Since cerebellar nuclei have a somatotopic map of the body, the connection of PFs to the cerebellar nuclear map by PCs could influence coordinated movements of multiple muscles and joints (Thach et al., 1992). Therefore, precise topographic organization of the PF-PC synaptic circuit is thought to be important for coordinated movements of body parts in animals. Because L7-Cre;Itpr $1^{\text {flox/flox }}$ mice have increased spine densities and decreased dendritic arbors, and these spines formed intact synapses with PF terminals in a one-to-one fashion, the spatial distribution of PF-PC synapses in the cerebellar cortex is presumably abnormal in adult L7-Cre; Itpr $1^{\text {flox/flox }}$ mice. Judging from the evidence that mGluR1, G $\alpha \mathrm{q}$, or PLC $\beta 4$ knock-out mice have not shown such apparent morphological abnormalities in PCs, the unexpected severity of ataxia

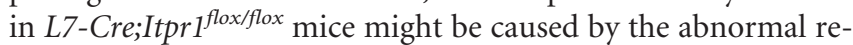
wiring of PF-PC synaptic circuits in the mature cerebellar cortex. The redundant contributions of AMPA receptor and PLC $\beta$ isoforms other than $\beta 4$ for $\mathrm{IP}_{3}$ production in PCs (Kano et al., 1998; Hirono et al., 2001; Okubo et al., 2001) most likely underlies the differences in PC morphological phenotypes between $\mathrm{L7}-\mathrm{Cre}$; Itpr $1^{\text {flox/flox }}$ and mGluR1, G $\alpha \mathrm{q}$, or PLC $\beta 4$ knock-out mice. Besides the abnormalities in PF-PC synaptic circuits, mild atrophic PC phenotypes with small soma size and decreased dendritic branching may also, at least in part, contribute to severe ataxic phenotype in L7-Cre; Itpr $1^{\text {flox/flox }}$ mice.

Recent studies have shown that the disruption of $\mathrm{IP}_{3} \mathrm{R} 1$ dependent signaling is linked to several types of human spinocerebellar ataxia (SCA; Schorge et al., 2010; Kasumu and Bezprozvanny, 2012). In SCA2 pathogenesis, polyglutamine-expanded ataxin-2 
specifically binds $\mathrm{IP}_{3} \mathrm{R} 1$ and increases the sensitivity of $\mathrm{IP}_{3} \mathrm{R} 1$ to activation by $\mathrm{IP}_{3}$, and this supranormal $\mathrm{Ca}^{2+}$ release via $\mathrm{IP}_{3} \mathrm{R} 1$ is important in cerebellar dysfunction (Liu et al., 2009; Kasumu et al., 2012). Alternatively, SCA15 patients have genetic deletion or mutation of the Itprl gene (van de Leemput et al., 2007; Hara et al., 2008; Iwaki et al., 2008; Di Gregorio et al., 2010; Novak et al., 2010). Moreover, an ataxic phenotype is observed in several spontaneous mutant mice with less $\mathrm{IP}_{3} \mathrm{R} 1$ expression (Street et al., 1997; van de Leemput et al., 2007). However, it is still not understood how disruption of $\mathrm{IP}_{3} \mathrm{R} 1$-dependent signals leads to cerebellar dysfunction in SCA pathogenesis. In this study, we demonstrated that the loss of $\mathrm{IP}_{3} \mathrm{R} 1$ function specifically in PCs is sufficient to cause ataxia without apparent $\mathrm{PC}$ loss, suggesting that $\mathrm{PC}$ loss itself is not essential for causing ataxia in the situation of $\mathrm{IP}_{3} \mathrm{R} 1$ loss of function. In addition, L7-Cre;Itpr $1^{\text {flox/flox }}$ mice showed abnormal PC spine maintenance, which was possibly associated with severe ataxia. Therefore, it is possible that the disruption of $\mathrm{PC}$ spine maintenance by $\mathrm{IP}_{3} \mathrm{R} 1$ deletion might be associated with the severity of ataxia in SCA15 pathology.

Although Kasumu et al. (2012) demonstrated that chronic depletion of $\mathrm{IP}_{3} \mathrm{R}$-dependent signaling by expressing the inositol 1,4,5-phosphatase enzyme in intact PCs caused PC degeneration and ataxia at 12 months of age, our L7-Cre; Itpr $1^{\text {flox/flox }}$ mice did not show PC loss at 10W (Fig. 2E), and even at 5 months of age (our preliminary observation; $n=1$ ). The low survival rate with less feeding due to severe ataxia in the adult $L 7-C r e ; I_{\text {tpr }} 1^{\text {flox/flox }}$ mice hinders gathering the data in aging L7-Cre; Itpr $1^{\text {flox/flox }}$ mice. Nevertheless, because SCA15 is characterized by late-onset ataxia in humans (Storey et al., 2001), further analysis with more aging L7-Cre; Itpr $1^{\text {flox/flox }}$ mice is required for clarifying this issue.

Recent studies have revealed that the structural rearrangement of spines caused by the induction of synaptic plasticity is associated with learning and memory in the cerebral cortex and hippocampus (Kasai et al., 2010). Several studies have also suggested that motor learning is associated with morphological changes in PC spines and PF-PC synapses in the cerebellum in vivo (Black et al., 1990; González-Burgos et al., 2011). However, in contrast to the cerebral cortex and hippocampus, PF-PC LTD induction did not cause any change in the spine density or size of PCs (Sdrulla and Linden, 2007), and many genetically modified mice lacking cerebellar LTD did not show any significant morphological abnormalities of PC spines (Aiba et al., 1994; De Zeeuw et al., 1998; Feil et al., 2003; Hansel et al., 2006; Steinberg et al., 2006; van Woerden et al., 2009), suggesting that PF-PC LTD does not trigger morphological changes in PC spines. Thus, structural PC spine rearrangement and PF-PC LTD are likely to be independently involved in cerebellar motor learning. PC $\mathrm{IP}_{3} \mathrm{R} 1$ is therefore thought to regulate spine morphology in addition to inducing PF-PC LTD, and the abnormalities in both spine morphology and PF-PC LTD induction may cause a severe impairment of motor learning in L7-Cre;Itpr $1^{\text {flox/flox }}$ mice.

In conclusion, we propose a specific role for $\mathrm{IP}_{3} \mathrm{R} 1$ in PCs not only as an intracellular mediator of LTD induction but also as a critical regulator of PF-PC synaptic circuit maintenance in the cerebellum of adult mice. Our L7-Cre;Itpr $1^{\text {flox/flox }}$ mice may provide a valuable experimental model to clarify the relationship between the maintenance and modification of PF-PC synapses and the expression of cerebellar functions in vivo.

\section{References}

Aiba A, Kano M, Chen C, Stanton ME, Fox GD, Herrup K, Zwingman TA, Tonegawa S (1994) Deficient cerebellar long-term depression and impaired motor learning in mGluR1 mutant mice. Cell 79:377-388. CrossRef Medline
Arshavsky YI, Gelfand IM, Orlovsky GN (1983) The cerebellum and control of rhythmical movements. Trends Neurosci 6:417-422. CrossRef

Barski JJ, Dethleffsen K, Meyer M (2000) Cre recombinase expression in cerebellar Purkinje cells. Genesis 28:93-98. CrossRef Medline

Berridge MJ, Lipp P, Bootman MD (2000) The versability and universality of calcium signaling. Nat Rev Mol Cell Biol 1:11-21. CrossRef Medline

Black JE, Isaacs KR, Anderson BJ, Alcantara AA, Greenough WT (1990) Learning causes synaptogenesis, whereas motor activity causes angiogenesis, in cerebellar cortex of adult rats. Proc Natl Acad Sci U S A 87:5568 5572. CrossRef Medline

De Zeeuw CI, Hansel C, Bian F, Koekkoek SK, van Alphen AM, Linden DJ, Oberdick J (1998) Expression of a protein kinase C inhibitor in Purkinje cells blocks cerebellar LTD and adaptation of the vestibulo-ocular reflex. Neuron 20:495-508. CrossRef Medline

Di Gregorio E, Orsi L, Godani M, Vaula G, Jensen S, Salmon E, Ferrari G, Squadrone S, Abete MC, Cagnoli C, Brussino A, Brusco A (2010) Two Italian families with ITPR1 gene deletion presenting a broader phenotype of SCA 15. Cerebellum 9:115-123. CrossRef Medline

Dueñas AM, Goold R, Giunti P (2006) Molecular pathogenesis of spinocerebellar ataxia. Brain 129:1357-1370. CrossRef Medline

Feil R, Hartmann J, Luo C, Wolfsgruber W, Schilling K, Feil S, Barski JJ, Meyer M, Konnerth A, De Zeeuw CI, Hofmann F (2003) Impairment of LTD and cerebellar learning by Purkinje cell-specific ablation of cGMPdependent protein kinase I. J Cell Biol 163:295-302. CrossRef Medline

Frederick AL, Saborido TP, Stanwood GD (2012) Neurobehavioral phenotyping of $\mathrm{G} \alpha \mathrm{q}$ knockout mice reveals impairements in motor functions and spatial working memory without changes in anxiety or behavioral despair. Front Behav Neurosci 6:29. CrossRef Medline

Furuichi T, Mikoshiba K (1995) Inositol 1,4,5-trisphosphate receptormediated $\mathrm{Ca}^{2+}$ signaling in the brain. J Neurochem 64:953-960. Medline

Furuichi T, Simon-Chazottes D, Fujino I, Yamada N, Hasegawa M, Miyawaki A, Yoshikawa S, Guénet JL, Mikoshiba K (1993) Widespread expression of inositol 1,4,5-trisphosphate receptor type 1 gene (Insp3r1) in the mouse central nervous system. Receptors Channels 1:11-24. Medline

González-Burgos I, González-Tapia D, Zamora DA, Feria-Velasco A, BeasZárate C (2011) Guided motor training induces dendritic spine plastic changes in adult rat cerebellar Purkinje cells. Neurosci Lett 491:216-220. CrossRef Medline

Guastavino JM, Sotelo C, Damez-kinselle I (1990) Hot-foot murine mutation: behavioral effects and neuroanatomical alterations. Brain Res 532:199-210. CrossRef Medline

Hansel C, de Jeu M, Belmeguenai A, Houtman SH, Buitendijk GH, Andreev D, De Zeeuw CI, Elgersma Y (2006) $\alpha$ CaMKII is essential for cerebellar LTD and motor learning. Neuron 51:835-843. CrossRef Medline

Hara K, Shiga A, Nozaki H, Mitsui J, Takahashi Y, Ishiguro H, Yomono H, Kurisaki H, Goto J, Ikeuchi T, Tsuji S, Nishizawa M, Onodera O (2008) Total deletion and a missense mutation of ITPR1 in Japanese SCA15 families. Neurology 71:547-551. CrossRef Medline

Hirano A, Dembitzer HM, Yoon CH (1977) Development of Purkinje cell somatic spines in the weaver mouse. Acta Neuropathol 40:85-90. CrossRef Medline

Hirono M, Sugiyama T, Kishimoto Y, Sakai I, Miyazawa T, Kishio M, Inoue H, Nakao K, Ikeda M, Kawahara S, Kirino Y, Katsuki M, Horie H, Ishikawa Y, Yoshioka T (2001) Phospholipase C $\beta 4$ and protein kinase $\mathrm{C} \alpha$ and/or protein kinase $\mathrm{C} \beta \mathrm{I}$ are involved in the induction of long term depression in cerebellar Purkinje cells. J Biol Chem 276:45236-45242. CrossRef Medline

Hisatsune C, Kuroda Y, Akagi T, Torashima T, Hirai H, Hashikawa T, Inoue T, Mikoshiba K (2006) Inositol 1,4,5-trisphosphate receptor type 1 in granule cells, not in Purkinje cells, regulates the dendritic morphology of Purkinje cells through brain-derived neurotrophic factor production. J Neurosci 26:10916-10924. CrossRef Medline

Ichise T, Kano M, Hashimoto K, Yanagihara D, Nakao K, Shigemoto R, Katsuki M, Aiba A (2000) mGluR1 in cerebellar Purkinje cells essential for long-term depression, synapse elimination, and motor coordination. Science 288:1832-1835. CrossRef Medline

Inoue T, Kato K, Kohda K, Mikoshiba K (1998) Type 1 inositol 1,4,5trisphosphate receptor is required for induction of long-term depression in cerebellar Purkinje neurons. J Neurosci 18:5366-5373. Medline

Ito M (1989) Long-term depression. Annu Rev Neurosci 12:85-102. CrossRef Medline 
Ito M (2002) The molecular organization of cerebellar long-term depression. Nat Rev Neurosci 3:896-902. CrossRef Medline

Ito M (2006) Cerebellar circuitry as a neuronal machine. Prog Neurobiol 78:272-303. CrossRef Medline

Iwaki A, Kawano Y, Miura S, Shibata H, Matsuse D, Li W, Furuya H, Ohyagi Y, Taniwaki T, Kira J, Fukumaki Y (2008) Heterozygous deletion of ITPR1, but not SUMF1, in spinocerebellar ataxia type 16. J Med Genet 45:32-35. Medline

Jastreboff PW (1979) Evaluation and statistical judgment of neural responses to sinusoidal stimulation in cases with superimposed drift and noise. Biol Cybern 33:113-120. CrossRef Medline

Jörntell H, Hansel C (2006) Synaptic memories upside down: bidirectional plasticity at cerebellar parallel fiber-Purkinje cell synapses. Neuron 52: 227-238. CrossRef Medline

Kano M, Hashimoto K, Watanabe M, Kurihara H, Offermanns S, Jiang H, Wu Y, Jun K, Shin HS, Inoue Y, Simon MI, Wu D (1998) Phospholipase C $\beta 4$ is specifically involved in climbing fiber synapse elimination in the developing cerebellum. Proc Natl Acad Sci U S A 95:15724-15729. CrossRef Medline

Kasai H, Hayama T, Ishikawa M, Watanabe S, Yagishita S, Noguchi J (2010) Learning rules and persistence of dendritic spines. Eur J Neurosci 32:241249. CrossRef Medline

Kasumu A, Bezprozvanny I (2012) Deranged calcium signaling in Purkinje cells and pathogenesis in spinocerebellar ataxia 2 (SCA2) and other ataxias. Cerebellum 11:630-639. CrossRef Medline

Kasumu AW, Liang X, Egorova P, Vorontsova D, Bezprozvanny I (2012) Chronic suppression of inositol 1,4,5-triphosphate receptor-mediated calcium signaling in cerebellar Purkinje cells alleviates pathological phenotype in spinocerebellar ataxia 2 mice. J Neurosci 32:12786-12796. CrossRef Medline

Katoh A, Kitazawa H, Itohara S, Nagao S (1998) Dynamic characteristics and adaptability of mouse vestibulo-ocular and optokinetic reflex eye movements and the role of flocculo-olivary system revealed by chemical lesions. Proc Natl Acad Sci U S A 95:7705-7710. CrossRef Medline

Katoh A, Kitazawa H, Itohara S, Nagao S (2000) Inhibition of nitric oxide synthesis and gene knockout of neuronal nitric oxide synthase impaired adaptation of mouse optokinetic response eye movements. Learn Mem 7:220-226. CrossRef Medline

Kim D, Jun KS, Lee SB, Kang NG, Min DS, Kim YH, Ryu SH, Suh PG, Shin HS (1997) Phospholipase C isozymes selectively couple to specific neurotransmitter receptors. Nature 389:290-293. CrossRef Medline

Korkotian E, Segal M (1999) Release of calcium from stores alters the morphology of dendritic spines in cultured hippocampal neurons. Proc Natl Acad Sci U S A 96:12068-12072. CrossRef Medline

Kurihara H, Hashimoto K, Kano M, Takayama C, Sakimura K, Mishina M, Inoue Y, Watanabe M (1997) Impaired parallel fiber $\rightarrow$ Purkinje cell synapse stabilization during cerebellar development of mutant mice lacking the glutamate receptor $\delta 2$ subunit. J Neurosci 17:9613-9623. Medline

Le TD, Shirai Y, Okamoto T, Tatsukawa T, Nagao S, Shimizu T, Ito M (2010) Lipid signaling in cytosolic phospholipase $\mathrm{A}_{2} \alpha$-cyclooxygenase- 2 cascade mediates cerebellar long-term depression and motor learning. Proc Natl Acad Sci U S A 107:3198-3203. CrossRef Medline

Lee KJ, Kim H, Rhyu IJ (2005) The roles of dendritic spine shapes in Purkinje cells. Cerebellum 4:97-104. CrossRef Medline

Liu J, Tang TS, Tu H, Nelson O, Herndon E, Huynh DP, Pulst SM, Bezprozvanny I (2009) Deranged calcium signaling and neurodegeneration in spinocerebellar ataxia type 2. J Neurosci 29:9148-9162. CrossRef Medline

Maeda N, Niinobe M, Mikoshiba K (1990) A cerebellar Purkinje cell marker $\mathrm{P} 400$ protein is an inositol 1,4,5-trisphosphate (InsP3) receptor protein. $\mathrm{Pu}$ rification and characterization of InsP3 receptor complex. EMBO J 9:61-67. Medline

Mariani J, Crepel F, Mikoshiba K, Changeux JP, Sotelo C (1977) Anatomical physiological and biochemical studies of the cerebellum from Reeler mutant mouse. Philos Trans R Soc Lond B Biol Sci 281:1-28. Medline

Matsumoto M, Nakagawa T, Inoue T, Nagata E, Tanaka K, Takano H, Minowa O, Kuno J, Sakakibara S, Yamada M, Yoneshima H, Miyawaki A, Fukuuchi Y, Furuichi T, Okano H, Mikoshiba K, Noda T (1996) Ataxia and epileptic seizure in mice lacking type 1 inositol 1,4,5-trisphosphate receptor. Nature 379:168-171. CrossRef Medline

Mikoshiba K (2011) Role of $\mathrm{IP}_{3}$ receptor in development. Cell Calcium 49: 331-340. CrossRef Medline

Miyata M, Kim HT, Hashimoto K, Lee TK, Cho SY, Jiang H, Wu Y, Jun K, Wu
D, Kano M, Shin HS (2001) Deficient long-term synaptic depression in the rostral cerebellum correlated with impaired motor learning in phospholipase C $\beta 4$ mutant mice. Eur J Neurosci 13:1945-1954. CrossRef Medline

Mizutani A, Kuroda Y, Futatsugi A, Furuichi T, Mikoshiba K (2008) Phosphorylation of Homer3 by calcium/calmodulin-dependent kinase II regulates a coupling state of its target molecules in Purkinje cells. J Neurosci 28:5369-5382. CrossRef Medline

Nakade S, Rhee SK, Hamanaka H, Mikoshiba K (1994) Cyclic AMPdependent phosphorylation of an immunoaffinity-purified homotetrameric inositol 1,4,5-trisphosphate receptor (type I) increases $\mathrm{Ca}^{2+}$ flux in reconstituted lipid vesicles. J Biol Chem 269:6735-6742. Medline

Nakao H, Nakao K, Kano M, Aiba A (2007) Metabotropic glutamate receptor subtype-1 is essential for motor coordination in the adult cerebellum. Neurosci Res 57:538-543. CrossRef Medline

Novak MJ, Sweeney MG, Li A, Treacy C, Chandrashekar HS, Giunti P, Goold RG, Davis MB, Houlden H, Tabrizi SJ (2010) An ITPR1 gene deletion causes spinocerebellar ataxia 15/16: a genetic, clinical and radiological description. Mov Disord 25:2176-2182. CrossRef Medline

Offermanns S, Hashimoto K, Watanabe M, Sun W, Kurihara H, Thompson RF, Inoue Y, Kano M, Simon MI (1997) Impaired motor coordination and persistent multiple climbing fiber innervation of cerebellar Purkinje cells in mice lacking Galphaq. Proc Natl Acad Sci U S A 94:14089-14094. CrossRef Medline

Ogura H, Matsumoto M, Mikoshiba K (2001) Motor discoordination in mutant mice heterozygous for the type 1 inositol 1, 4, 5-trisphosphate receptor. Behav Brain Res 122:215-219. CrossRef Medline

Okubo Y, Kakizawa S, Hirose K, Iino M (2001) Visualization of IP ${ }_{3}$ dynamics reveals a novel AMPA receptor-triggered $\mathrm{IP}_{3}$ production pathway mediated by voltage-dependent $\mathrm{Ca}^{2+}$ influx in Purkinje cells. Neuron 32: 113-122. CrossRef Medline

Patel S, Joseph SK, Thomas AP (1999) Molecular properties of inositol 1,4,5-trisphosphate receptors. Cell Calcium 25:247-264. CrossRef Medline

Schorge S, van de Leemput J, Singleton A, Houlden H, Hardy J (2010) Human ataxias: a genetic dissection of inositol triphosphate receptor (ITPR1)-dependent signaling. Trends Neurosci 33:211-219. CrossRef Medline

Sdrulla AD, Linden DJ (2007) Double dissociation between long-term depression and dendritic spine morphology in cerebellar Purkinje cells. Nat Neurosci 10:546-548. CrossRef Medline

Sharp AH, McPherson PS, Dawson TM, Aoki C, Campbell KP, Snyder SH (1993) Differential immunohistochemical localization of inositol 1,4,5trisphosphate- and ryanodine-sensitive $\mathrm{Ca}^{2+}$ release channels in rat brain. J Neurosci 13:3051-3063. Medline

Shutoh F, Ohki M, Kitazawa H, Itohara S, Nagao S (2006) Memory trace of motor learning shifts transsynaptically from cerebellar cortex to nuclei for consolidation. Neuroscience 139:767-777. CrossRef Medline

Sotelo C (1977) Formation of presynaptic dendrites in the rat cerebellum following neonatal X-irradiation. Neuroscience 2:275-283. CrossRef Medline

Sotelo C, Dusart I (2009) Intrinsic versus extrinsic determinants during the development of Purkinje cell dendrites. Neuroscience 162:589-600. CrossRef Medline

Steinberg JP, Takamiya K, Shen Y, Xia J, Rubio ME, Yu S, Jin W, Thomas GM, Linden DJ, Huganir RL (2006) Targeted in vivo mutations of the AMPA receptor subunit GluR2 and its interacting protein PICK1 eliminate cerebellar long-term depression. Neuron 49:845-860. CrossRef Medline

Storey E, Gardner RJ, Knight MA, Kennerson ML, Tuck RR, Forrest SM, Nicholson GA (2001) A new autosomal dominant pure cerebellar ataxia. Neurology 57:1913-1915. CrossRef Medline

Street VA, Bosma MM, Demas VP, Regan MR, Lin DD, Robinson LC, Agnew WS, Tempel BL (1997) The type 1 inositol 1,4,5-trisphosphate receptor gene is altered in the opisthotonos mouse. J Neurosci 17:635-645. Medline

Tanaka M (2009) Dendrite formation of cerebellar Purkinje cells. Neurochem Res 34:2078-2088. CrossRef Medline

Tomomura M, Rice DS, Morgan JI, Yuzaki M (2001) Purification of Purkinje cells by fluorescence-activated cell sorting from transgenic mice that express green fluorescent protein. Eur J Neurosci 14:57-63. CrossRef Medline

Thach WT, Goodkin HP, Keating JG (1992) The cerebellum and the adap- 
tive coordination of movement. Annu Rev Neurosci 15:403-442. CrossRef Medline

van de Leemput J, Chandran J, Knight MA, Holtzclaw LA, Scholz S, Cookson MR, Houlden H, Gwinn-Hardy K, Fung HC, Lin X, Hernandez D, Simon-Sanchez J, Wood NW, Giunti P, Rafferty I, Hardy J, Storey E, Gardner RJ, Forrest SM, Fisher EM, et al (2007) Deletion at ITPR1 underlies ataxia in mice and spinocerebellar ataxia 15 in humans. PLoS Genet 3:e108. CrossRef Medline

van Woerden GM, Hoebeek FE, Gao Z, Nagaraja RY, Hoogenraad CC, Kushner SA, Hansel C, De Zeeuw CI, Elgersma Y (2009) $\beta$ CaMKII controls the direction of plasticity at parallel fiber-Purkinje cell synapses. Nat Neurosci 12:823-825. CrossRef Medline

Yoshikawa F, Iwasaki H, Michikawa T, Furuichi T, Mikoshiba K (1999) Trypsinized cerebellar inositol 1,4,5-trisphosphate receptor. Structural and functional coupling of cleaved ligand binding and channel domains. J Biol Chem 274:316-327. CrossRef Medline

Yuzaki M (2012) Cerebellar LTD vs. motor learning — lessons learned from studying GluD2. Neural Netw. Online publication. Retrieved June 19, 2013. doi:10.1016/j.neunet.2012.07.001. CrossRef Medline 